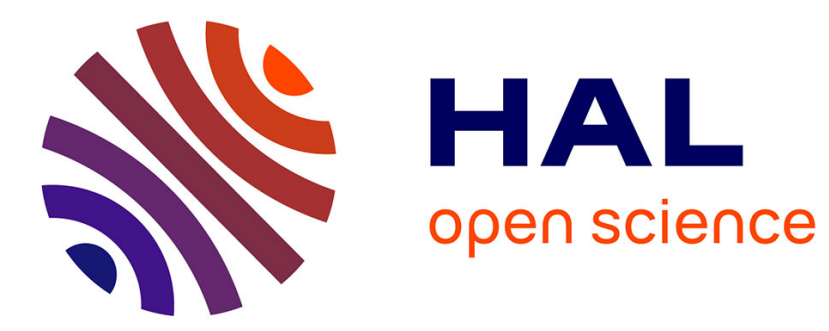

\title{
Categorising combinations of farmers' land use practices: an approach based on examples of sheep farms in the south of France
}

Nathalie N. Girard, Stephane Bellon, Bernard Hubert, Sylvie Lardon, Charles-Henri Moulin, Pierre-Louis Osty

\section{To cite this version:}

Nathalie N. Girard, Stephane Bellon, Bernard Hubert, Sylvie Lardon, Charles-Henri Moulin, et al.. Categorising combinations of farmers' land use practices: an approach based on examples of sheep farms in the south of France. Agronomie, 2001, 21 (5), pp.435-459. 10.1051/agro:2001136 . hal00886130

\section{HAL Id: hal-00886130 \\ https://hal.science/hal-00886130}

Submitted on 1 Jan 2001

HAL is a multi-disciplinary open access archive for the deposit and dissemination of scientific research documents, whether they are published or not. The documents may come from teaching and research institutions in France or abroad, or from public or private research centers.
L'archive ouverte pluridisciplinaire HAL, est destinée au dépôt et à la diffusion de documents scientifiques de niveau recherche, publiés ou non, émanant des établissements d'enseignement et de recherche français ou étrangers, des laboratoires publics ou privés. 
Original article

\title{
Categorising combinations of farmers' land use practices: an approach based on examples of sheep farms in the south of France
}

\author{
Nathalie GIRARD ${ }^{a *}$, Stéphane BELLON ${ }^{\mathrm{a}}$, Bernard HubERT ${ }^{\mathrm{a}}$, Sylvie LARDON ${ }^{\mathrm{b}}$, \\ Charles-Henri MouLIN ${ }^{\mathrm{c}}$, Pierre-Louis OsTY ${ }^{\mathrm{d}}$ \\ ${ }^{a}$ INRA-SAD, Domaine Saint-Paul, 84914 Avignon Cedex 9, France \\ b INRA-SAD, 2 place Viala, 34060 Montpellier Cedex 1, France \\ ${ }^{c}$ INRA-SAD and ENSAM, 2 place Viala, 34060 Montpellier Cedex 1, France \\ ${ }^{\mathrm{d}}$ INRA-SAD, BP 27, 31326 Castanet-Tolosan Cedex, France
}

(Received 7 September 2000; revised 29 March 2001; accepted 3 April 2001)

\begin{abstract}
Territorial stakes that now include environmentally friendly agriculture and farmer participation in space management make it necessary to review farm diversity in order to include their spatial organisations in this re-qualification. The objective of our approach was to formally categorise farms on the basis of land use practices. For this, we used a set of examples of sheep farms in the south of France together with knowledge engineering methods. Using a combination of eight attributes that characterise the farmland use practices, we were able to work out four major farmland use prototypes. The general principles of this categorisation approach are innovative because of the chosen criteria (the farmland utilisation) and of the final form of the categories allowing to represent graduality. Results obtained make it possible to examine the relations of these farms to space and time, which could be of great interest for better understanding of farms' possible evolution in the current perspective of agriculture role in space management.
\end{abstract}

husbandry practices / typology / grazing land / sheep farming / farmland use / knowledge modelling

Résumé - Catégoriser les combinaisons de pratiques d'utilisation du territoire par les agriculteurs : une démarche à partir de cas en élevage ovin du Sud de la France. Les nouveaux enjeux territoriaux, d'une agriculture plus respectueuse d'environnement et de la participation des agriculteurs à la gestion de l'espace, appellent à re-qualifier la diversité des exploitations agricoles, de manière à rendre compte de leurs organisations spatiales. Nous présentons une démarche dont l'objectif était de formaliser des catégories d'exploitations agricoles à partir des pratiques d'utilisation du territoire mises en œuvre par les agriculteurs. Nous nous sommes appuyés conjointement sur un ensemble de cas d'élevages ovins du Sud de la France et sur des méthodologies d'ingénierie des connaissances. Nous avons ainsi dégagé quatre grands prototypes d'utilisation du territoire, à partir des combinaisons de huit attributs caractérisant les pratiques d'utilisation du territoire de ces cas. Les principes généraux de cette démarche de catégorisation d'exploitations agricoles sont novateurs à la fois dans les critères pris en compte (les pratiques d'utilisation du territoire) et dans la forme finale de ces catégories permettant de représenter la gradualité. Les résultats obtenus nous permettent finalement d'examiner les rapports des exploitations à l'espace et au temps, ce qui pourrait être une aide précieuse pour mieux cerner les évolutions possibles de ces exploitations dans les perspectives actuelles d'implication de l'agriculture dans la gestion de l'espace.

pratiques d'élevage / typologie / espace pâturé / production ovine / utilisation du territoire / modélisation de connaissances

Communicated by Gérard Guyot (Avignon, France)

* Correspondence and reprints

girard@ toulouse.inra.fr

Present address: INRA-SAD, BP 27, 31326 Castanet-Tolosan Cedex, France 


\section{INTRODUCTION}

How farmers develop their activities in a given land area is an important question, especially considering the new issues related to the environment. This question is becoming more topical for de-intensification of livestock systems, incited to increase grazing. Conversely, in many mountainous or hilly areas in Europe, only livestock farming is considered able to manage the landscape and keep it open, by maintaining scrub encroachment and natural extension of woodland. But the way livestock producers use the land will be strongly affected by socio-economic issues such as the renewal of its population, the dynamism of the market sub-sector that it supplies and the assistance provided for this agriculture that occupies and develops areas. Unfortunately, there is no model to report the conditions of this land use, and there is no mechanism for ongoing observation in order to detect and evaluate perceivable changes in these farming systems.

This explains the need to design new theoretical frameworks and methodological approaches to deal with these questions which have been little considered in agronomic research during the last few decades. This need concerns all the production systems but the livestock production systems are unquestionably the ones that are the first to be queried about their manner of using the lands. Yet in this specific field, science has focused mainly on improving performance in animal husbandry through breeding, feeding, and animal health. The relation to plant resources focused on food production and the nutritive value of the plant biomass, thereby leading to technical recommendations for the plots being grazed.

As a consequence, most work is focused on objects such as the plot or the batch of animals, while the farmland taken globally is not considered. From a systemic point of view, the organisational level of farming systems remains little studied. Agricultural research is henceforth expected to produce concepts and knowledge needed to advance the utilisation modes of grazing lands on the whole. The change involved is expected to lead to a reallotment of lands in the livestock production systems, all the while respecting the diversity of these systems. In fact, diversity guarantees the capacity to manage heterogeneous lands (slopes, soils, orientations, etc.), which runs counter to the standardisation produced by uniform production models. The second methodological expectation from agricultural research is its ability to represent this diversity both as a snapshot and dynamic phenomenon. This is what we are trying to contribute to in this article.
The case of extensive farming systems in southern France from which we draw the methodological elements presented in this paper represents a relevant experience in this double perspective of land use practices modelling and diversity recognition. Paradoxically these systems, which for a long time were considered to be marginal, have been "modernised" (animal breeds, materials, feed, herders' know-how, etc.), so that they are now interesting to study both in order to reason out the management of land areas in harsh zones and to help in designing de-intensified systems for lowland areas. In this area, despite a tradition of pastoral husbandry, the position of such farms in space seems, on the whole, to be at the breaking point, although innovative solutions are being devised at the local level. In one century [10], sheep husbandry, the foundation of the agro-pastoral subsistence systems, has become a market-oriented production system in a classical scenario of dwindling populations, land concentration and falling back in the most productive areas. With an eye on the use of space, the "saltus", i.e. the traditional grazed part of agricultural areas in Mediterranean regions, distinct from "ager" (cropping areas) and "silva" (forest) $[8,11]$ is still of major importance for agro-pastoral systems which, in particular, manage fertility of cropping-land by flocks, unlike other regions where it has been turned into forestland. Furthermore, the cultivable lands have not been converted into grasslands since they are still part of a rotation system dominated by fodder legumes. This explains why the various entities of the land that can be identified within each farm are, in functional terms, connected to each other via the farmers' activities, e.g. animal production, equipment assignment, labour organisation. Farmers' practices thus govern the organisation of the land areas of each farm through optimal use of soil types, land exposition, slopes of the various spatial entities and by creating interaction and complementarity among them.

This makes it difficult for the aforementioned organisation to be intelligible unless the underlying practices, which are also varied from one farmer to the next, can be understood. This is why we use case studies for constructing an approach to the categorisation and interpretation of the livestock producers' land use practices. In the first part, we searched through recent literature to find the elements needed to describe and characterise these practices. In the second part, we presented our approach, which starts with surveys that do not require complex monitoring mechanisms. It draws on the theory of prototypes in cognitive sciences in order to formalise farmland use practices. After presenting our results, we discuss the significance of the farmland use prototypes that we identified. They are first situated at an intermediary level, between the plots and the batched animals 
level and the farm level which challenge usual objects of scientific knowledge. Second, these prototypes suggest time-space management units that could be useful in providing a framework for the scientific work expected of the agronomists and the interventions expected of the extension officers and trainers/educators.

\section{REPRESENTING THE SPATIAL ORGANISATION OF A FARM: ACQUIRED KNOWLEDGE AND SPECIFIC FEATURES OF FARMLAND UTILISATION FOR LIVESTOCK}

How can the spatial organisation of a farm be defined and represented? What entities are relevant in reporting farmland use practices? How can the combination of these practices in time and space be represented and made intelligible? These issues are central to our research and challenge both geographers, who study the organisation of space, and agronomists who are interested in how farms function.

\subsection{Spatial organisation and farms}

As a starting definition, we propose that the spatial organisation of a farm is constituted by the inter-relations created by the farmer in the spatial entities of his farmland. Our purpose is therefore to consider these entities not only as individual plots, buildings and equipment, but as interlinked by the production system organisation and to characterise them regarding their functions in this system.

In geography, spatial organisation can be defined as a "more or less coherent combination of areas that have been inter-connected" [14]. Geographers working on the organisation of space have tried to analyse and lend meaning to observed forms. Some models are based on economic principles, e.g. Von Thünen's concentric model which cites production as a function of distanceto-market, or Christaller's model on central places which ranks links between places according to the services offered (quoted in [34]). In a less formal manner, Sautter [74] (a geographer specialising in the tropics), showed the link between spatial organisation and human functioning on given terroirs (land areas with special features) and brings out both polarities and contrasts. Here, the analysis of spatial organisation of land occupancy prioritises the distance to noteworthy sites such as housing, roads, water points, etc. [23]. Lastly, some regional studies designed to characterise land use types refer to the identification of intermediary scalar units, which are relatively homogeneous as concerns their use in agriculture. These entities may be part of a terroir [49], landscape units [77] or agro-physionomic units [22]. Except for the last few studies, not many geographers have researched the spatial organisation of farms from the point of view of farmers' practices.

\subsection{Spatialisation of agricultural activities and spatial entities in agronomy}

Conversely, many agronomists have been interested in farm practices, but up to now little work has been focused directly on characterising the spatial organisations of farms.

\subsubsection{The importance of environmental factors in analysing farmland utilisation}

Many authors mainly use pedoclimatic determinants when trying to understand how farmers use their lands. There are some structural characteristics (topology of plots and buildings: plot size, shape and layout, in particular, distance to farmstead) that also affect the way farmlands are used $[4,13,61]$. This is especially true in the case of extensive farming, which reveals more of the environment, as Papy and Viaux [67] showed concerning low-input cropping systems.

In some situations, a correspondence between land cover and farm types can be discovered [27], but, as Milleville and Dubois [58] evidenced by showing how differently farmers used identical lands in similar environments, it is not possible to consider that the environment alone determines farmland utilisation. These observations largely support the importance of studying farmers' practices in which, we feel, the farmers incorporate the characteristics and heterogeneity of the environment to meet their own objectives.

\subsubsection{Beyond the plot to consider the farm level}

Other agronomic research focused on modelling cultivated fields, especially cropping plots, which are spatial entities considered relevant a priori for analysing yield composition [24]. This object has proven to be especially instructive, especially in linking technical interventions with their effects on the crop field. Nonetheless, as many agronomists realised that the level of spatial organisation needed to study some questions (such as labour organisation, investment in the farm, equipment, the new relationship with agro-industrial plants, ...) was higher than that of the crop field, they felt encouraged to move from the cultivated field to the farm level [16]. 


\subsubsection{Models at the farm level that prioritise the temporal organisation of technical acts}

Up to now, studies on farmers' practices usually gave major importance to the temporal organisation of decisions. The concept of the action model [75] for instance made it possible to model annual decisions as connected planned phases. But prioritising time segments usually means leaving aside spatial organisation although this question is beginning to be considered in livestock farming [36].

By going beyond the case studies on farmers' decisions and practices, some scientists were able to identify farm types [17, 69]. But here again, spatial organisation is not considered since the farm is viewed as a frame within which production techniques are carried out.

\subsubsection{Farm-level models that integrate spatial aspects}

Spatial aspects can be integrated in farm models in two manners:

- by a posteriori spatialisation of agronomic variables, as was done by Benoit [6] for the per plot nitrogen status needed to evaluate the risk of nitrate leaching, by Mignolet [57] for farm typologies, and by Pierret et al. [71] concerning rules farmers applied when allocating plots. But this a posteriori spatialisation cannot explain relations between farm type and corresponding farmland;

- by explicitly modelling spatial entities used by the farmers.

Thus, as Meynard [56] suggested, concerning the protection of a groundwater table, we consider that studying the spatial organisation of a farm requires specific modelling, which is more than merely adding up the plots being cultivated. We support the approach [e.g. 7, 51] taken on spatial management of cropping systems.

The cropping pattern concept [35], defined as an annual allocation of farmlands to crops that have the same technical characteristics, is not necessarily spatialised. Nonetheless, the study of cropping patterns has inspired some scientists to define spatial entities on which standardised techniques are applied, e.g. land area occupied by these crops [2], blocks of plots [12, 72].

Going beyond the crop year proper, the choice of a year's cropping pattern affects the following years' patterns because of crop sequencing rules (rotations) and the perennial nature of some crops such as temporary grasslands. The overall organisation of a cropping area in a farm, thus, can thus be considered as a timed coordination for several rotations on a series of plots [76] or as a combination of crop sequences [53]. Aubry et al. [3] have suggested identifying blocks of cropfields (series of cropped plots used for given crop sequences) and then the organisation of blocks of cropped plots (according to labour, terrain, or plot constraints).

These approaches to choices of cropping pattern all include procedures to combine cropped plots, procedures which, in particular, consider common characteristics (terrain, type of land cover, rotations, relative size and distance of plots) and show that land use impacts spatial structure through functional relations among crops.

These types of spatial models are probably valid for the cultivated parts of livestock farms, but they ignore many other parts, from the rangelands to the perennial plant plots (grasslands or legumes) which, in agronomy, are not often studied from the spatial vantage point. Further, farmland used by herds/flocks has specific characteristics which we think need to be taken into account.

\subsection{Special characteristics of farmland utilisation in grassland and pastoral livestock farms}

Farmland utilisation in livestock farms is organised on the basis of:

- the capacity of the animals to move around, which, because of grazing, interrelates heterogeneous and distant land areas (cultivated lands and perennial vegetation such as the rangelands);

- grazing, as an act which requires temporal consistency between the successive patterns of utilisation, according to "grazing modes" (a concept similar to crop management sequence in agriculture) and which "diversifies the states of these resources".

A spatial model on how farms use the land, like the one we want to construct, must explicitly include these specific characteristics. Some tools that describe these practices have been produced [21], but as yet, there are very few models that cover the combination of these practices. On the contrary, much research has been devoted to identifying spatial entities for animal rearing because the farmland units are difficult to define a priori since the plots can be grouped in one way at some period of time, and differently at others, and animals may be assigned in batches.

\subsubsection{Spatial entities between the feeding station and the "quartier"'}

Spatial entities suggested for analysing farmland utilisation by a herd give different relative importance to

\footnotetext{
${ }^{1}$ The quartier is defined as "all zones that are accessible to a herd/flock from a single night-time assembly point" (Hubert et al. 1993).
} 
space and time. For instance, to report farmland utilisation in a grassland suckler cattle farm, Josien et al. [41] propose two types of spatial entities, "islets" i.e. nearby or neighbouring groups of plots separated by an obstacle that impedes animal movement, and, blocks, i.e. groups of plots assigned to a given batch of animals for the grazing season. This analysis focuses on animal movement and farmland structural constraints (access, dispersal of plots and fodder resources, distance between plots and buildings, etc.), and thus fits well a rather structured grazing calendar, the kind that applies to suckler cows.

These entities cannot simply be reassigned to small ruminants, which graze a wide diversity of resources because they do not properly adapt to the granularity of the grazing calendar. Because of the mobility of the animals, the herder can have his flock grazing different, sometimes distant parts of the land during a single season and, in shepherding systems, even within a single day. He can, for instance, combine cultivated plots with heterogeneous rangelands as part of a single grazing circuit, thus linking a variety of sites and improving animal intake [54].

In these goat-and-sheep farms, the spatial entities range from a feeding station in a grazing circuit to more vast areas like the iso-utilisable zones described by Auricoste et al. [4]. In the rest of this text, we will use the quartier ${ }^{1}$ as the potentially relevant entity for our situations. The quartier must be distinguished from a "sector" which we define as "the area used during the days that a herd/flock treks over a grazing circuit of a given type" (adapted from [52]). When studying the feeding behaviour of a grazing flock, Laca and Ortega [43] even suggested connecting different spatio-temporal levels of organisation from the feeding station to the quartier. Although the spatial entities used by the herder when guiding his animals can be identified by implementing these approaches, they cannot make the herder's combination of practices intelligible, and the spatial organisation models of these farms are still implicit.

\subsubsection{Organising and organised utilisation practices}

Our work espouses the model proposed by Guérin and Bellon [33] who represented the temporal organisation of flock grazing through the linkage of "functions" that match farmland areas and animal batches. In this model, space is implicitly represented by the group of farmland areas that, during a period of the year called the "saisonpratiques" [5] fulfils a function based on a time-spacebatch relationship ${ }^{2}$. Our brief, thus, was to continue

\footnotetext{
${ }^{2}$ For instance, "maintaining ewes on summer ranges in the middle of summer" or "supporting lactation for suckler ewes by combining grazingland and rangeland in late spring".
}

along the same lines, while explicitly integrating the spatial aspects.

Taking the herders' practices specifically as the centre of our research and as the starting point for the forthcoming model, we adopted the position put forth by Biarnes and Milleville [9] for whom the technical act is an object of research in itself and not just one more explanatory variable. These practices are organised since they reflect the farmer's rationale, and play an organising role and since they structure land use i.e. past grazing leads to an ordering of future resources, crop sequences impose spatio-temporal structuring, etc. The modalities of these practices can be observed, and their effects can be seen in the landscape, the state of the vegetation, the soil profile, etc.

In concrete terms, we have identified two groups of practices [63]. Some practices can be linked to the farmland configuration (Fig. 1), and correspond to a specific event, identified by its date (date of location of a new plot) on a multi-year time scale. Their origin lies in the history of the farm, and they affect its structure, (acquiring or relinquishing land areas, creating equipment or buildings, rehabilitation of farmland areas by e.g. removing stones from a plot). Other practices are connected to land use on a crop year scale. They correspond to assignments, e.g. of a group of animals to a grazing area or a handling pen, or of a crop to a plot. So the description of a practice includes the association between entities, but it also dwells on the conditions of the actions carried out during this association (a crop assigned to a plot, with a given management sequence).

Our project thus consisted of constructing a model of the spatial organisation of sheep farming, starting with the analysis of land use practices by sheep farmers who constitute the common core of our research. The model is supposed to answer two questions, viz. (1) how to identify types of organisation through the combination (in time and space) of land use practices in sheep farming, and (2) are there a few major types of spatial organisation for these farms? The spatial entities used by the sheep farmers thus are not an entry point; they will emerge as the model is being constructed.

\section{RESEARCH PROTOCOL: INFORMATION USED AND PROCEDURE}

To answer these questions, we tried to construct spatial organisation categories of sheep farms by formalising the farmers' practices for his farmland utilisation, these practices being the common focus of our previous approaches [37, 46, 62]. Actually, in order to go beyond analysing cases and their similarities and thus to produce 


\begin{tabular}{|c|c|c|}
\hline \multirow{4}{*}{$\begin{array}{l}\text { Configure- } \\
\text { one-time actions, } \\
\text { timed to occur } \\
\text { throughout the years, } \\
\text { which change the structure } \\
\text { of the farmland }\end{array}$} & \multirow{2}{*}{ - Build up the farmland - } & \multirow{2}{*}{$\begin{array}{l}\text { - Land acquisition } \\
\text {-Abandon the land }\end{array}$} \\
\hline & & \\
\hline & \multirow{6}{*}{$\begin{array}{l}\text { Lay out the farmland - } \\
\text { Create points, } \\
\text { lines, networks } \\
\text { that structure } \\
\text { the farmland }\end{array}$} & Build animal restraining equipment \\
\hline & & Build storage equipment (materials, harvests, etc.) \\
\hline & & -Develop circuits (trails, tracks, etc.) \\
\hline & & Develop distribution points (water, etc.) \\
\hline & & - Install fencing \\
\hline & & Develop networks (irrigation, drainage, etc.) \\
\hline & \multirow{4}{*}{$\begin{array}{l}\text { Rehabilitate the farmland } \\
\text { Develop areas }\end{array}$} & Stone removal \\
\hline & & Bush clearance \\
\hline & & Fertilisation \\
\hline & & etc. \\
\hline \multicolumn{3}{|c|}{\begin{tabular}{l|l} 
Utilise & Assign crops to plots
\end{tabular}} \\
\hline $\begin{array}{l}\text { one-time or repeated } \\
\text { actions through the year }\end{array}$ & \multicolumn{2}{|c|}{\begin{tabular}{|l} 
Assign animals to handling pens \\
Assign batches of animals to grazing lands
\end{tabular}} \\
\hline
\end{tabular}

Figure 1. Configuration and land use practices in sheep rearing.

operational knowledge, we had to transform individual characteristics into categories. Our approach drew on a theory of categorisation that comes from cognitive sciences and on methodologies used in knowledge engineering.

\subsection{A multi-site setting based on surveys}

\subsubsection{A series of sheep farm cases in the south of France}

The case studies in this paper came from three research operations. The locations were a valley in the Prealpine region near Digne in the Alpes de HauteProvence [37], the Causse Méjan in Lozère [46] and the garrigues (mediterranean shrubby vegetation on calcareous terrain) by Montpellier in the Hérault region [62]. The natural environment of these three sites is different, ranging from the dry mountains along the Mediterranean to the calcareous high altitude plateaus and the Cévennes plains and foothills, but their common denominator is that all have rangelands that have been grazed by sheep for many years [59]. The sheep farms were selected to match the aims of each specific research operation, but the choice also bore in mind the need for diversity, either on the basis of farm stratification (e.g. for Montpellier, cases were chosen according to a typology of farms), or of contrast in management practices (such as breeding management in the Prealpine site).

A set of 16 farms, for which the data we required were already available, was designed. The main activity of these farms is sheep-farming with flocks of between 200 and 700 ewes. Some also engage in crop farming. The farms have rangelands (100-750 ha), with or without cropping areas (up to $75 \mathrm{ha}$ ), and display great diversity, e.g. the Causse Méjan farm has dairy sheep, all three sites produce meat, some practise transhumance (animals in the Prealpine region are taken to the summer rangelands, more distant movement for animals in the garrigues). There are differences in breeding management for dairy sheep farms, with one, two or three lambings per annum.

\subsubsection{Data used}

Most of our data concerned land use practices during the crop year and were described in relation to various time plans called calendars. Some practices corresponded to one-only events (e.g. turning a batch of animals out 
to grass) while others applied to repeated daily actions (e.g. every day for two weeks the flock is taken out to graze for ten hours a day in the same paddock). We also referred to earlier land utilisation and configuration practices in order to roughly define the framework within which the sheep farmers carried out their land use practices each year.

We have the following data for each of the 16 cases:

- map of the farmland showing the various areas, their present plant cover and background, their equipment and buildings. Some are more detailed than others (IGN map at a scale of 1/25000, aerial photos, land survey plans for the Causse Méjan and the Prealpine region; a rough drawing based on an IGN map at a scale of $1 / 25000$ and identification of some of the relief and infrastructure for the farms in the garrigues);

- a calendar that provides at least a one year description for the herd batches at pasture (batches formed to be kept housed at night were not included), and the assignment of batches to grazing sites or handling pens. Accuracy and reliability differ from case to case. Accuracy also differs from one research operation to the next. These calendars were recorded (1) as they were being carried out or were reconstructed for the preceding year in the Prealpine region, (2) for several years in the Méjan and (3) only once in the garrigues;

- cropping pattern (for studies that only covered one crop year and crop sequences (when several consecutive crop years are described).

\subsection{Prototypic categories to represent similarity and typicality}

In order to go beyond individual characteristics of the cases we studied, and to construct categories of spatial organisation for the farms, we used categorisation, in particular the prototype theory, stemming from cognitive sciences.

\subsubsection{The origin of the prototype theory}

The prototype theory [73] in cognitive sciences was a major move away from the classical categorisation model, and can be traced to the following assertions:

- some common concepts are defined in terms of the similarity between the members of the category, in other words, properties that are found in some, but not necessarily all cases, rather than in terms of the char- acteristics that all the members of the category have in common;

- a category has fuzzy borderlines: a case can often be classified between two categories, such as the tomato that is both a vegetable and a fruit;

- the typicality phenomenon which indicates the existence of a degree of "representativeness" within a category, since some cases are more typical than others (like the sparrow, which is a bird par excellence vs. the ostrich which is often called a "funny bird" [25]).

\subsubsection{Contribution of prototypes in constructing categories of farms}

Prototypes $^{3}$ make a twofold contribution to our field since they provide categories:

- that can be defined starting from the centre, the point of logic, rather than "from the outside in". This makes it possible to represent the fact that farms are part of a continuum constructed around major lines of logic rather than in a partitioned space;

- that can be used to see how well a case fits in various categories by assigning a degree of similarity per category rather than assigning it to a partitioned category in a Boolean manner. A farm can thus be analysed as a specific combination of several categories. Our hypothesis is that this specific combination, when reduced to the cognitively useable dimensions of a few prototypes, can enable an extensionist to better adapt his work to the farmers' needs.

Some authors, like Perrot [68], although they do not explicitly cite the prototype theory as a reference, support this theory by building up farm types around "aggregation poles".

\subsubsection{The internal organisation of a prototypic category, the calculation of similarity between a case and a prototype}

A prototypic category is composed of a series of attributes together with their possible associated modalities (an attribute-modality pair being a property); each attribute has a specific weight that corresponds to its contribution to the definition of the category. In general, weights are assigned to the different modalities of an attribute; this is how information is introduced to the variability an attribute is allowed to have between the different members of the category. But weights can also

\footnotetext{
3 "Prototype" or "category" are then interchangeable words in our work.
} 
be assigned to the different attributes in a manner that introduces a hierarchy among the attributes in the definition of the category. Actually some attributes play a more typical role than others in defining a category.

In order to define how well a case fits a category, its similarity to the prototype is calculated by adding up the contribution of each of the case's properties. The calculation of all the similarities of possible members of a category then provides a similarity scale.

\subsubsection{An attractive theory, a formalisation procedure yet to construct}

This prototype theory is very appealing because of its capacity to represent knowledge on the structure of the world as perceived and manipulated by individuals in their actions, but, up to the present, it has been used primarily to allow experimenters to portray categories of biological and manufactured objects that are stored in a memory [25]. Consequently, it does not provide much help in formalising new categories. Further, it has seldom been used for the social objects we are dealing with here, which are more complex, evolutive, and strongly context-related, as Huteau [38] pointed out.

This meant that we had to build up a procedure for formalising prototypic categories as we went along, especially as concerned choices on weighting attributes and modalities. We used the following approach.

\subsection{Approach used to formalise categories}

We followed a three step approach (presented in detail in [32]) which partly overlapped in time and was composed of:

- formalisation of prototype attributes (3.3.1.);

- combination of eight attributes formalised in order to define four prototypes for grazingland utilisation (3.3.2.);

- calibration of these prototypes (3.3.3.).

\subsubsection{Formalisation of prototype attributes}

The "repertory grids" taken from knowledge engineering were used in this step [29]. A repertory grid is a series of dichotomic attributes (represented graphically as bipolar axes) that place two poles opposite each other, and can be used to represent an evaluation of a case according to a gradient scale.

This method was of use in the first step of our approach when we formalised eight attributes that corre- sponded to the attributes ${ }^{4}$ that we perceived as being distinct in our 16 cases (cf. Tab. I). For each of the attributes, the farmers' various practices were formalised into 3 to 5 modalities, organised in terms of these attributes. Each farmer was connected to one, but only one modality (Fig. 2).

We stopped the formalisation process at the point where the defined attributes and their modalities enabled us to describe, for each case, the noteworthy traits, related to the logic underlying the case's use of grazinglands. This decision was substantiated retrospectively by the possibility of constructing relevant spatial organisation types as combinations of these attributes, which required some iterations between the two steps.

\subsubsection{Combining the different attributes to roughly describe the prototypes}

By combining the attributes as defined above, we were able to build up prototypes on the utilisation of grazinglands. To do this, we used diverse representations of the modalities for our 16 cases, according to these attributes.

- Star-formed diagrams to depict the modalities of the eight attributes for each case

This, the first type of representation, involves looking at each case as an 8-branch star shape, a branch for each attribute, which makes it possible to see the raw data for the combination of attributes in the 16 cases as well as to visually conceptualise overall shapes and to group cases according to the similarity of these shapes (see an example in Fig. 3).

\section{- Representing the cases in a two-dimensional space}

This type of representation is designed to position each case in a diagram composed of two attributes. Crossing the attributes two by two brings out some similarities among the cases as well as prohibited combinations of modalities, e.g. because of technical incompatibilities.

\section{- Analysing the multidimensional crossing of the eight attributes}

Since manual and cognitive multidimensional crossing of the sets of attributes would be impossible, we used WebGridII, one of the many processing tools for the repertory grids [29]. We chose it because of its availability

\footnotetext{
${ }^{4}$ We will refer in the rest of the paper to "attributes" only, even if they are graphically represented as bipolar axes.
} 
The farmer

shepherds his flock Case

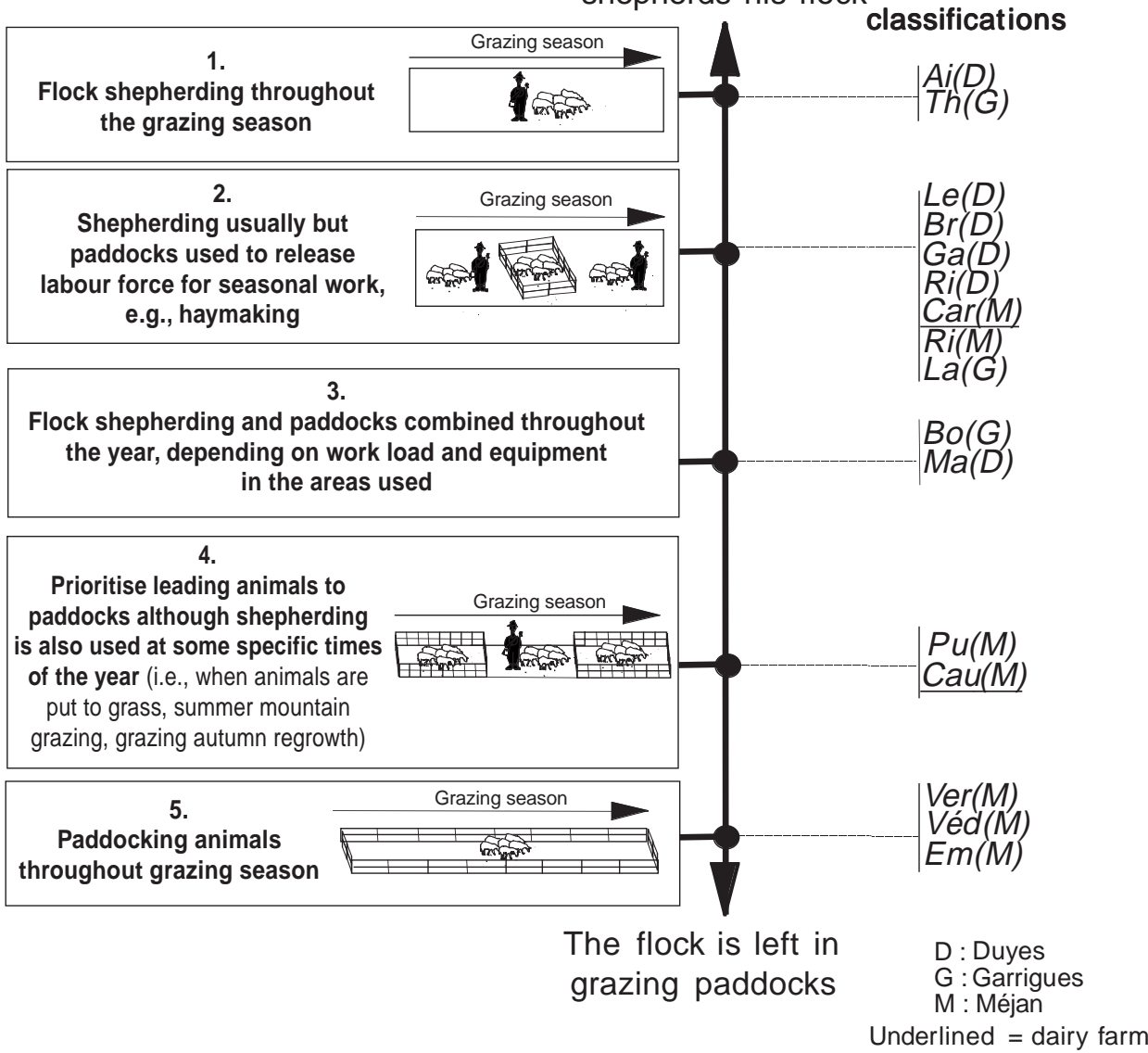

Figure 2. An example of an axis that defines one attribute to characterise land use practices.
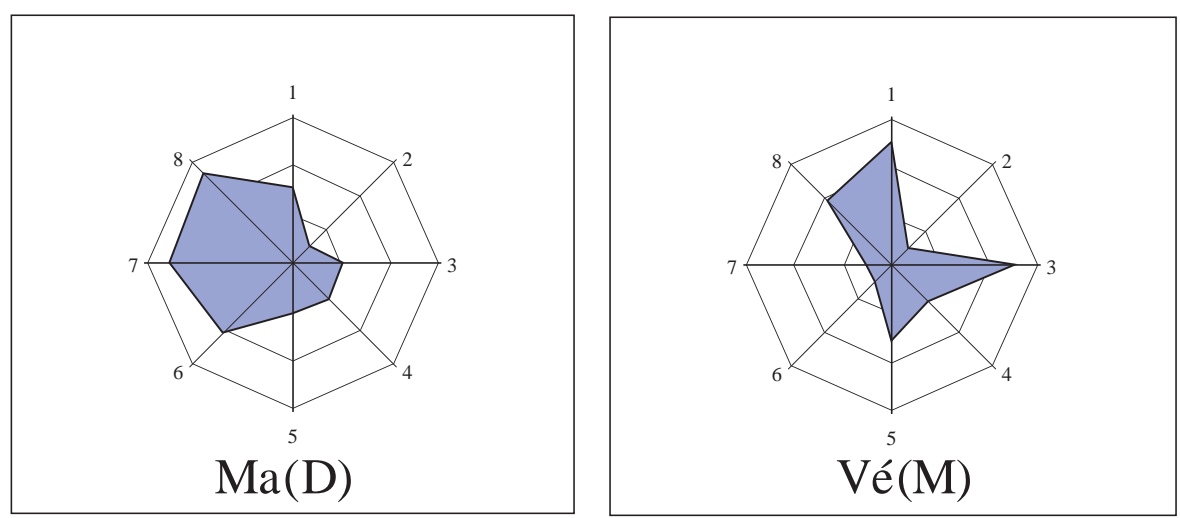

Figure 3. An example of star-formed diagrams to depict the modalities of the eight attributes for two cases Ma(D) and Vé(M). 
on the Web, its interactiveness and the graphic representations it proposes. These tools are based on a classical principal component analysis and require coding of the attribute modalities on a quantitative scale, which was problematic for us because our attributes, i.e. farmers' practices, are naturally qualitative. In a very traditional manner, these tools produce hierarchical classification trees that serve to cluster groups of cases that have the strongest similarities.

These representations have enabled us to roughly describe the correlation among the attributes, and the similarities among the cases.

\subsubsection{Calibrating prototypes}

The representations constructed herein above enabled us to very globally distinguish farm groups with combinations of grazingland-use practices that revealed different underlying logic.

We then studied the frequency with which the various modalities for the eight attributes in these groups of cases occurred. In a group that had all the modalities of an attribute, the attribute did not provide any information on the group's underlying logic. For example, almost all modes of leading animals to the grazing lands can be found (see Fig. 2) in two groups of cases. On the contrary, it is a major characteristic for the third group within which all the cases actually show two modalities that are close to each other (shepherding, exclusively or in most cases). For each of the prototypes, we thus distinguished the typical and the non-typical attributes.

Finally, this analysis of case groups and their similarities in terms of attribute modalities enabled us to assign weights that represent the frequency of occurrence of the different attribute modalities in each group (see Sect. 4.3).

This approach was applied to our 16 sheep farms and enabled us to work out eight attributes and four prototypes of grazingland use; they are presented in detail in the following section.

\section{RESULTS: PROTOTYPES OF GRAZINGLAND UTILISATION}

Section 4.1 presents the attributes distinguished to characterise farmland use practices, and Section 4.2 presents their combinations in prototypes. In Section 4.3 we go back to our approach to detail the calibration of these prototypes using the available cases, and propose a formal representation. Finally, in Section 4.4 we use these prototypes to characterise, in a different manner, the farms we studied.

\subsection{Eight attributes to characterise farmland use practices}

Table I presents the eight constructed attributes and their distinguished modalities for the 16 cases studied. These attributes describe farmland utilisation: distant summer mountain pastures, which are often communal, are not included in the analysis since the choice of dates for going to and leaving them, and flock management on the mountain ranges is not solely up to the farmer. The attributes characterise flock management during the grazing season (in some cases all year long if the flock is reared year-round outdoors).

\subsubsection{Four attributes related to land configuration and production system}

These attributes describe the land use context for a period of one year, the use per se is more directly described by the other four attributes.

- Night-time penning (Attribute 1) distinguishes shepherds who drive the animals to a given location (sheepfold, handling pen, milking parlour) every evening from the ones who leave the animals in a - generally fenced off - grazing area. This practice is constrained by the availability of appropriate related equipment, which will have been installed as part of configuration practices (see Fig. 1) carried out in previous years. Here, the choice impacts the farmer's work (daily obligation to bring in the animals or supervision for a given time) and also the flock's radius of movement, i.e. all of the areas to which the herder believes he can take his animals and back in one day from the night-time assembly point.

- Management of distance the animals must cover to reach the grazing area (Attribute 2) is also connected to the equipment (buildings, fencing). The use of most distant zones depends on the location of equipment and the mode of night-time containment. It also depends on the herder's perception of flock mobility (a herder may want to keep down movement by lactating ewes while the dry ewes may be driven farther) and the accessibility of various parts of his territory (a nearby plot may be deemed difficult to access if it entails crossing a road). Some herders do not have any distance problems since all of their area (often compactly structured) is accessible, while others overcome potential problems by installing equipment (decentralised sheepfolds so that all of the zone can be reached from these night-time assembly points, or enclosed grazing areas with year-round outdoors rearing), and still others cope with the distance problem 
by only using some zones during given seasons or for particular batches of animals.

- Leading animals to pasture (Attribute 3) explains whether the herder tends his animals or whether he "parks" them using mechanical means such as permanent fencing or mobile netting. This attribute is connected to the organisation of work (tending the flock throughout the grazing season is an activity that requires one person, full time) and the equipment on the land.

- Batching flocks for grazing (Attribute 4) amounts to a definition of the number and nature of the animal batches concerned by the land use practices. This attribute distinguishes between the case in which the farmland is used by one batch, i.e. the flock, and the case of flocks that are always divided into several batches. It is connected to animal husbandry parameters such as lactation, breeding or lamb-finishing management, and also to land management. The complexity of animal batching is connected to the organisation of labour and equipment, e.g. single batches are preferred in situations where farm chores are heavy and labour is scarce; multiple batching is often possible when grazing paddocks are available.

\subsubsection{Two attributes to characterise land use by flocks divided into more or less mobile batches}

- Land use granularity (Attribute 5) describes the smallest spatial unit in the pasture area to which a flock (or a batch) is allocated. Some herders choose zones with homogeneous food resources during a given time period; this depends on the preceding use of the zone, on what the animals have consumed prior to reaching the zone and on what the herders want them to consume afterwards $[36,55]$. The elementary use units may be easy to identify e.g. plots on cultivated grasslands used in quick spring rotations, or difficult to identify e.g. in the case of the shepherded animals' circuit. In the latter case, reconstituting the grazing calendar is tedious. Other herders, on the contrary, prefer leaving their animals throughout the year in areas that have various plant associations from which the animals are left rather free to choose and build up their own diets. Such a zone may be composed of an enclosed paddock or a physical unit where the flock may display a special spatial and intake behaviour. In this scenario, the grazing calendar is easier to reconstitute.

- Some herders specialise their farmland entirely on the basis of saison-pratiques (in terms described in [5]), in other words, they allocate the flock to an area for a given season without returning there later. Other herders, on the contrary, take animal batches over the whole area during all saisons-pratiques. This "Land use specialisation" (Attribute 6) is different from the utilisation granularity: a specialised area can be used with "fine granularity" (the herder allocates his flock to plots because of the resources available in an area specialised for springtime use), or with "coarse granularity" (the herder uses an area reserved for spring grazing, composed of adjacent sectors).

\subsubsection{Two attributes to characterise the role of grasslands in flock feeding}

Grasslands have two main roles: to provide fodder for winter feeding and serve as a food source for grazing animals. They are usually all grazed in the fall, but have a variety of uses in the spring. That is why we are looking at these two attributes in relation to herders' springtime practices.

- The "Role of fodder areas in building up supplies and in springtime grazing" (Attribute 7) is connected to the amount of available grassland in the cropping pattern. A herder, therefore, who has very little grassland (pro rata the size of his flock, the length of the wintering period, and his production targets) will reserve it for building up hay supplies. Conversely, if fodder production areas are large enough to grow the supplies needed for winter, the herder may set aside part of the grasslands for springtime grazing.

- Relations between rangelands and grasslands in springtime grazing (Attribute 8) depends on the preceding attribute, of course. A herder who keeps all of his grasslands as stores (or does not have any) has to put the animals on the rangelands in the spring. On the other hand, herders who have access to grasslands in the spring can choose different rangeland/grassland combinations, even going as far as only using the grasslands, if they have enough land.

\subsection{Prototypes formalised on the basis of these eight attributes}

By combining these eight attributes we were able to roughly describe three prototypes, each depicting a different grazingland utilisation rationale. We added a fourth one (Prototype IV) which we felt was representative enough to merit a category of its own. This is in fact an innovative situation which is increasingly frequent in 
Table I. Attributes and modalities defined to characterise land use practices.

\begin{tabular}{|c|c|}
\hline Attributes & Modalities \\
\hline 1. Night-time penning & $\begin{array}{l}\text { 1. House flock at night all year long } \\
\text { 2. House flock at night most of the time } \\
\text { 3. Leave flock outdoors regardless of season }\end{array}$ \\
\hline $\begin{array}{l}\text { 2. Management of distance the animals } \\
\text { must cover to reach the grazing area }\end{array}$ & $\begin{array}{l}\text { 1. Use of small, compactly structured grazing land: whole area accessible within one day } \\
\text { from a given starting point } \\
2 \text {. Use of large compactly structured grazing land: use of some zones constrained } \\
\text { by distance } \\
\text { 3. Use of land structured according to starting points (several sheepfolds) thereby making } \\
\text { whole area accessible from one starting point } \\
\text { 4. Use of land equipped with enclosure thus making whole zone accessible throughout } \\
\text { the year }\end{array}$ \\
\hline 3. Leading animals to pasture & $\begin{array}{l}\text { 1. Tending flock throughout grazing season } \\
\text { 2. Preference for flock shepherding } \\
\text { 3. Combining flock shepherding and paddocks } \\
\text { 4. Prefer paddock-based management } \\
\text { 5. Keep flock in paddocks throughout grazing season }\end{array}$ \\
\hline 4. Batching flocks for grazing & $\begin{array}{l}\text { 1. Drive flock to grazing land in one batch throughout the year } \\
\text { 2. Remove animals needing care from the flock: two batches during one period } \\
\text { 3. In some periods, separate various categories of animals } \\
\text { 4. Drive animals in batches to grazing lands, flock regrouped at some periods of time } \\
\text { 5. Drive animals in batches to grazing lands throughout the year }\end{array}$ \\
\hline 5. Land use granularity & $\begin{array}{l}\text { 1. Lead the animals to sectors, combining different resources, where they can freely } \\
\text { make up their own rations } \\
\text { 2. Partly control constitution of ration of animals led to a given sector } \\
\text { 3. Lead flock (or batches) to sectors or to resources according to time of year } \\
\text { 4. Control ration consumed by flock most of the time, and leave animals free on the sector } \\
\text { some of the time } \\
\text { 5. Control ration consumed by flock by containing animals in an area that offers the } \\
\text { targeted resource }\end{array}$ \\
\hline 6. Land use specialisation & $\begin{array}{l}\text { 1. Fully specialise area according to saisons-pratiques } \\
\text { 2. Specialise area by saisons-pratiques, and return to all areas in the fall } \\
\text { 3. Specialise area by saisons-pratiques, except a few zones } \\
\text { 4. Specialise some zones by saisons-pratiques within a non-specialised area } \\
\text { 5. Go to all areas throughout the year }\end{array}$ \\
\hline $\begin{array}{l}\text { 7. Role of fodder areas in building up } \\
\text { supplies and in springtime grazing }\end{array}$ & $\begin{array}{l}\text { 1. Reserve some existing grasslands }(<3 \text { ares/ewe) as stores } \\
\text { 2. Choose between reserving grasslands for stores (and have leeway) or graze part and } \\
\text { have no leeway in the stores } \\
\text { 3. Have enough grassland ( } 5 \text { ares/ewe) to allow part to be grazed }\end{array}$ \\
\hline $\begin{array}{l}\text { 8. Relations between rangelands and } \\
\text { grasslands in springtime grazing }\end{array}$ & $\begin{array}{l}\text { 1. Graze rangeland throughout springtime, starting when animals are turned out to grass } \\
\text { 2. Combine grasslands and rangeland in daily grazing throughout springtime } \\
\text { 3. Animals on grassland before going to rangeland } \\
\text { 4. Graze mainly grasslands during springtime }\end{array}$ \\
\hline
\end{tabular}

the area we studied because of land availability, subsidies for procuring fencing equipment, and the development of new activities in the rural area, including some non-agricultural activities. Although we only encountered it once in our sample, Prototype IV then represents a wider diversity of cases.
Prototype I: Ensure grazing by driving flock to resources available during each season

According to this rationale, the land is compactly structured and polarised by its main buildings, including a sheepfold where the flock is housed every evening, 
regardless of season. The flock is shepherded and assembled in a single batch. The grazing calendar seems very "fragmented": there are many land use units and the zones have not been specially allocated on a saison-pratiques basis. The herdsman shepherds his flock to the resources available year-round, and land use granularity is very fine. Grazing circuits regularly combine various resources within a given day; grasslands are grazed (before or after mowing) in spring, together with the rangelands.

\section{Prototype II: Sequential grazing of rangelands while building up stores elsewhere}

Regardless of its configuration, farmland is always organised into sectors. The flock is tended and taken back to the sheepfold every evening; it is rarely divided into batches. The grasslands are reserved for haymaking and as of spring, most grazing is in the rangelands. The rangeland areas are divided into rather clearly differentiated sectors and are specialised by saison-pratiques. Land use granularity is coarser than for the preceding prototype; the herder's choice concerning flock allocation to land predicates more on equipment (fencing, water points) than on fodder resources.

Prototype III: Organise grazing throughout the farmland by seasonal combinations of quartiers and animal batches, and of grasslands and rangelands

For most of the year, the flock is divided into several batches for which the herder combines various possibilities of land use; combinations are sequential (mowing then grazing a grassland, shepherding then penning, or the opposite) or simultaneous (grasslands and rangelands in the same grazing day). These batches are thus allocated throughout the year to quartiers (and to sheepfolds for the night) in a multipolar land area. These practices result in some specialisation of the land's quartiers, but nonetheless allow for the possibility of rather detailed daily assignment and reassignment. Spring grazing combines rangelands and grasslands, the latter being strictly reserved for grazing.

\section{Prototype IV: Year-round outdoors rearing to make best use of the farmland}

The farmland area does not have a sheepfold, thus is not polarised, but it is entirely fenced and partitioned, and the grasslands are reserved for haymaking. The ewes only graze the rangelands. Each paddock is specialised, in keeping with the saisons-pratiques, as a result of the flock's moving around from one paddock to the other, according to a rather specific season-related time plan.

\subsection{Calibration of prototypes}

As explained in Section 3.3.3, the description of these prototypes was then used to:

- define the typicality of the attributes for each prototype (4.3.1.);

- assign, to the different attribute modalities, weights that represent frequency of occurrence in each prototype (4.3.2.).

\subsubsection{Weighting the attributes for each prototype}

We distinguished 3 types of attributes:

- attributes that are typical of the prototype, i.e. that are decisive for the grazingland use logic. These typical attributes are assigned a weight of 1 ;

- attributes that are not typical but contribute to making a case belong more strongly to a prototype. These are second order criteria in relation to the logic of grazingland use and, as secondary attributes, are assigned a weight of 0.5 ;

- attributes that are neutral in relation to the prototype, thus do not count in its definition and are assigned a weight of 0 .

Attribute 8 on the type of resource grazed in spring, for instance, is neutral for prototype I, for which spring can be spent just as well on grasslands as on rangelands. This attribute, therefore, is assigned a weight of 0 for this prototype; whatever type of resource is grazed in the springtime, the contribution of this attribute to similarity with the case studied, for prototype I, will be nil.

Table II reports the weights that we gave 8 attributes for the 4 prototypes so that each of the 8 attributes contributes to the definition of at least one of the 4 prototypes.

Table II. Weights allocated to 8 attributes for the 4 prototypes.

\begin{tabular}{lcccccccc}
\hline Attributes & 1 & 2 & 3 & 4 & 5 & 6 & 7 & 8 \\
\hline Prototype I & 0.5 & 1 & 1 & 1 & 1 & 0.5 & 0.5 & 0 \\
Prototype II & 0.5 & 0 & 0 & 0.5 & 1 & 1 & 1 & 1 \\
Prototype III & 0.5 & 1 & 0 & 1 & 0.5 & 1 & 0.5 & 1 \\
Prototype IV & 1 & 1 & 1 & 0 & 0.5 & 0.5 & 1 & 0.5 \\
\hline
\end{tabular}

\subsubsection{Weighting the modalities of the attributes}

Modalities were weighted by examining the groups of cases that were close to the prototypes and the frequency of occurrence of different modalities of each attribute in these groups. 


\subsubsection{Weighting modalities of qualitative attributes}

Most of the attributes have qualitative modalities which describe what to do in descriptive and graphic terms; these modalities are ranked between two extremes. Each modality is thus arbitrarily assigned a weight.

Weights given to modalities range between -100 and +100 , as follows:

- Neutral modalities found in cases that are deemed to belong to the prototype, or to cases outside the category are assigned a weight of 0 ;

- Typical modalities are assigned a weight of +100 ;

- Peripheral modalities, i.e. modalities found in members of the category but that are less typical of the category are assigned positive weights of between 0 and 100 in order to account for the frequency of occurrence of this modality;

- Forbidden modalities, i.e. modalities that are contradictory to the logic of grazingland use are assigned a negative weight of between -100 and 0 in order to penalise such cases in the calculation of similarity to the prototype.

For example, in Prototype I, shepherding alone (modality 1 of Attribute 3 ), or shepherding sometimes combined with fencing (Modality 2 of Attribute 3), have weights of 100 (typical modalities of the prototype), but the herder also has the option, with respect to this logic, to more broadly combine paddocks and shepherding (Modality 3 of Attribute 3), a practice which was arbitrarily weighted to 75. Similarly, for Prototype II, since animals typically spend the springtime on the rangelands (weight +100$)$, cases in which animals spend the springtime on the grasslands (a practice which is considered as contradictory to the prototype logic) would be penalised in order to reduce their similarity to the prototype (weight-100).

\subsubsection{Weighting modalities for Attribute 7 (the role of fodder areas in building up supplies and in springtime grazing)}

In the case of Attribute 7, a quantitative variable which is represented by the number of ares of grassland per ewe, we assigned each possible modality of this variable a degree of similarity to each prototype (Fig. 4).

We want this weighting to represent the following hypotheses:

- since the herders' possible choices will differ according to the per ewe range of grassland area, we consider that under 3 ares, the herder cannot apply type I or III logic (which are based on fodder area grazing) to farmland utilisation. Similarly, beyond 7 ares, it seems illogical to use the land in a very pastoral manner, as in types II and IV. Between these two limits, the chosen weighting made it possible to express the graduality of a case's similarity to the different logics;

- we decided to divide the per ewe grassland area in half in the dairy farms so as to be able to compare them to suckler farms, our assumption being that, on average, fodder area requirements in the spring are twice as high in the dairy systems. Actually, according to [39], energy requirements of dairy ewes in spring, during lactation, are $150 \%$ that of suckling ewes that lamb at the end of winter and $280 \%$ that of suckling ewes that lamb in the fall. As concerns land areas needed to constitute stores, dairy ewe feeding strategies require fodder supplies of between 350 and $500 \mathrm{~kg}$ per animal while fodder stores in the meat sheep feeding strategies are under $150 \mathrm{~kg}$ in the Mediterranean mountains and foothills [48].

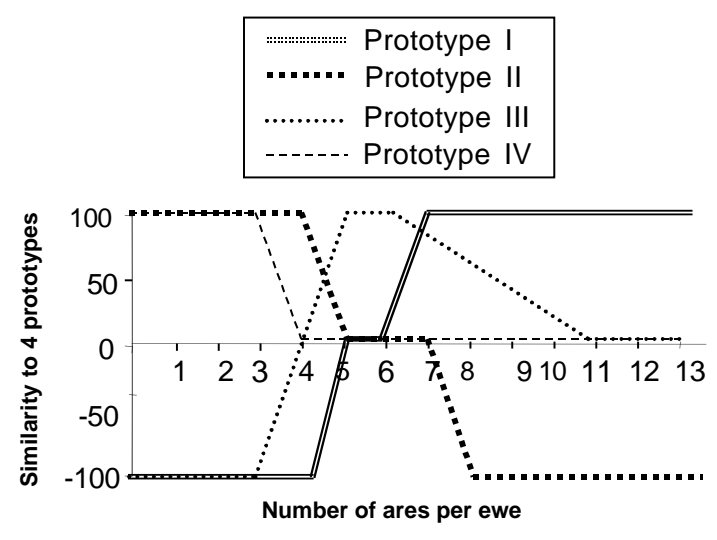

Figure 4. Similarity to the 4 prototypes in relation to number of ares of grassland per ewe.

\subsubsection{Iterations among similarities of the 16 cases and weights assigned to the modalities of the attributes}

To calibrate our prototypes, we drew up numerous iterations between the cases, using similarity calculations and weights assigned to the modalities of the attributes. Similarity $\mathrm{S}$, of case $\mathrm{X}$ to a $\mathrm{Y}$ prototype is calculated in the following manner:

$\mathrm{S}(\mathrm{X}, \mathrm{Y})=\Sigma_{\mathrm{i}}(\mathrm{p}(\mathrm{Y})($ Attribute $\mathrm{i}) \times \mathrm{p}(\mathrm{Y})(\operatorname{Modality}(\mathrm{X})) / \mathrm{SM} \times 100$ with

- $\mathrm{p}(\mathrm{Y})$ (Attribute i) being the weight for Attribute (0, 0.5 or 1) in Prototype Y; 
- $\mathrm{p}(\mathrm{Y})(\operatorname{Modality}(\mathrm{X}))$ being the weight of the modality as presented by $\mathrm{X}$ (between -100 and +100 ) for Attribute i, in Prototype Y;

- SM, the score of the best example of the category, in terms of this formal description of the category, is specific to each category. As this maximal score is computed by taking the weighted sum of the best modalities for each attribute, the "best example" is virtual and may not actually exist.

The similarity thus corrected to meet the maximal score is somewhere between 0 and 100 . The distances calculated in this way between cases and each prototype then allow us to correct the weights given first arbitrarily to attributes and modalities, in order finally to obtain a satisfactory picture of the diversity of our sample.

Figure 5 gives the example of similarities of the 16 cases to the four prototypes. Regarding Prototype I for example, four of the 16 cases $(\mathrm{Ga}(\mathrm{D}), \mathrm{Ri}(\mathrm{D}), \mathrm{Le}(\mathrm{D})$, $\mathrm{Ca}(\mathrm{M})$ ) have similarity levels of over $90 \%$ and can be considered as the core of the prototype. The herder who practices year-round outdoor rearing shows a negative similarity because his mode of land utilisation is so far away from this prototype. The position of other cases, with intermediate similarity, like $\mathrm{Ma}(\mathrm{D})$, for instance, is less clear.

\subsection{Use of prototypes to characterise our case studies}

To build up the characterisation of our cases beyond that provided by a simple calculation of their proximity to the prototypes, we are including data obtained from earlier studies on these cases [37, 46, 62]. These data include elements that might explain the limits or, on the contrary, the potentials for these farms, as concerns their
Prototype I

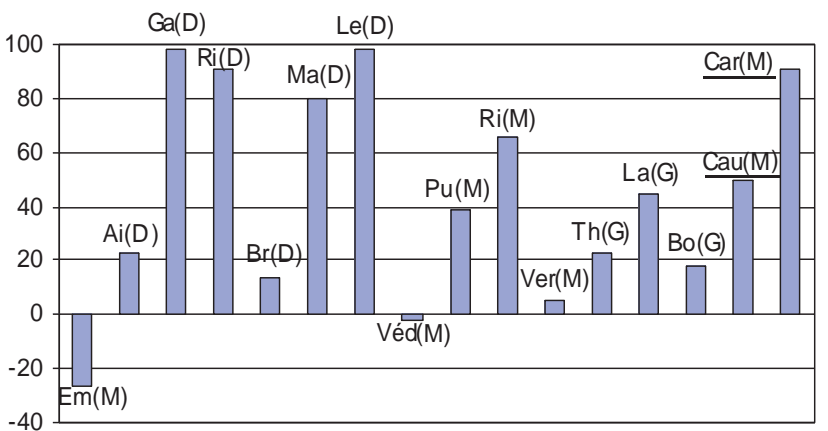

Prototype II

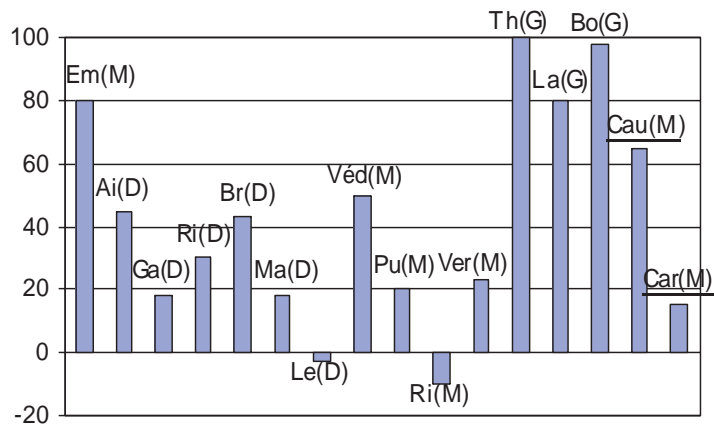

Prototype III

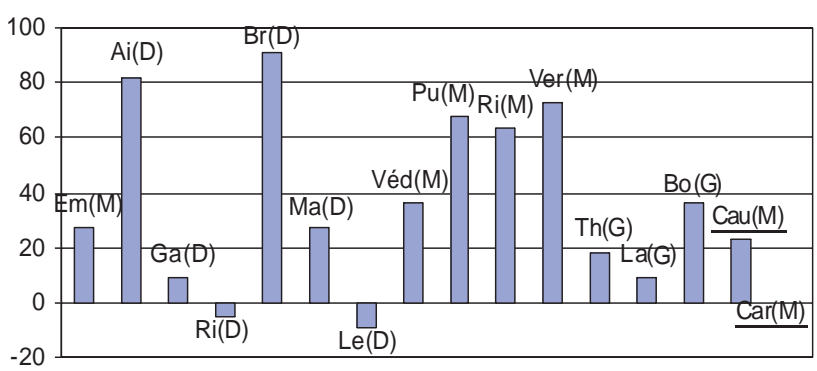

Prototype IV

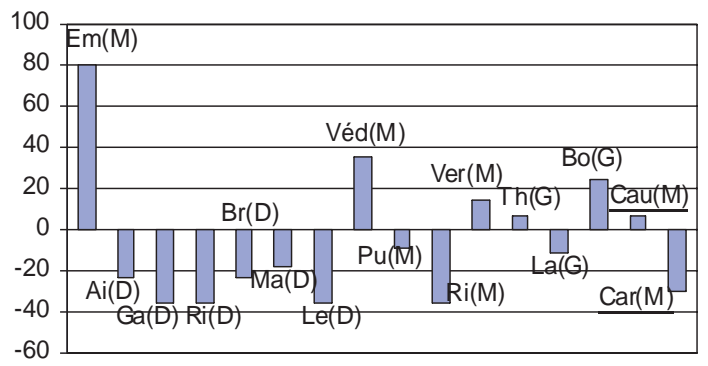

Figure 5. Calculation of similarities for the 16 cases to each prototype.

The $X$-axis shows the cases. The $Y$-axis gives the similarity of each case in relation to each prototype. (D): Duyes; $(M): M e ́ j a n ;(G)$ : Garrigues. Underlined: dairy farms. 
sizes, relative importance of crops and grasslands in relation to the pastoral lands, labour constraints, and system flexibility (bearing in mind their configuration, and adaptability to major changes).

\section{Prototype I: Ensure grazing by driving flock to resources} available during each season

These farming systems depend on careful matching of the flock (which is rarely divided into batches and is housed at night) and the resources of a land, that is diversified but forms a compactly structured territory. The farms are usually not very big (200 to 300 ewes, 15 to 20 ha of cultivated land and about a hundred hectares of grassland) and were configured long ago. The main cropping patterns we identified were composed of fodder crops (legumes often associated with grasses); most of the fields were small and dispersed throughout the farmland. It is not unusual to find them in the middle of grasslands far away from the farmstead. Within a given configuration, farmland use is very flexible since grazed resources can be substituted for each other from one circuit to the next. This flexibility is made possible thanks to the herders' knowledge of the interactions among plant resources needed to make up the animals' daily ration.

These systems are labour intensive and require more than one full-time person. Furthermore, they are not very adaptable because an increase of area or in animal numbers may jeopardise land configuration and utilisation. This means that the system could move towards other prototypes, such as III, as was the case for one of the herders we tracked (see MaD in Fig. 5) who passed from Prototype I to Prototype III within a few years. At the time of the study, he showed similarity with the two prototypes: after doubling his animal numbers, he acquired a third quartier, thus accentuating the multipolar character of his farmland.

\section{Prototype II: Sequential grazing of rangelands while building up stores elsewhere}

Here we are dealing with pastoral farms since most of the grazing comes from native resources on the rangelands. The animals driven in a single flock make the most of the diversity of these resources. Land use thus depends on the shepherd's knowledge of the grazing areas where he takes his animals to satisfy their feeding requirements.

Most of these farms are large suckler farms (more than 500 ewes and several hundred hectares of rangelands), but there are also smaller dairy farms. Both are specialised in animal rearing. The farmers that have grasslands use them exclusively for feeding their animals.
These sheep farming systems, like the preceding ones, are very labour intensive because of shepherding requirements. They are probably even less adaptable because specialised areas (at the same distance) can seldom be substituted for each other. On the other hand, the systems can adapt rather easily to increased herd sizes or opportunities linked to land availability thanks to the installation of paddocks, even rather large ones. This places them closer to Prototype IV.

Prototype III: Organise grazing throughout the farmland by seasonal combinations of quartiers and animal batches, and of grasslands and rangelands

These systems are based on the development of a farmland that has been broken down into several "poles", usually following a movement to increase the size of the farms in the first group.

They are medium size (400 ewes, over 20 ha of cropped lands, and 100-200 ha of rangeland) and have a large fodder base that makes up about $60 \%$ of the grassland in the cropping pattern. Crop rotation is mainly legumes ( 3 to 6 years) followed by cereals ( 2 to 3 years) that may eventually be sold.

Like the preceding ones, these systems are labour intensive. Constraints include distance and equipment maintenance.

The system's flexibility, given climatic uncertainty and possible readjustments in labour organisation, ensures satisfactory passage of the grazing season. The farmers' know-how combines thorough knowledge of their farmland's exploitable resources with well planned organisation of farmland use.

These systems are relatively adaptable to opportunities linked to land availability and can probably absorb increases in herd sizes... just by increasing or adapting their equipment. This of course presupposes availability of funding.

Prototype IV: Year-round outdoors rearing to make best use of the farmland

The pastoral farming systems here are based on yearround outdoors rearing.

These are large scale systems - hundreds of ewes, hundreds of hectares of rangeland - which require a holistic ad hoc design that goes as far as choosing hardy breeds that can be reared exclusively in the open. In most cases, they have been created by herders who are newcomers or just received an inheritance.

These systems do not absolutely require a fodder base, a fact that does not prevent the operators from working on plant production on other parts of their land; 
they do not have the problem of distance to grazing nor cropping patterns when designing cropping systems, as we have been able to see in Prototypes I and III.

In this scenario, the demanding job of animal supervision is replaced by timebound tasks such as changing the paddocks, or regularly checking the condition of the fencing. And, every few years, less frequent tasks need to be done, e.g. equipment maintenance or checking the condition of the plots.

This animal rearing system is designed to easily incorporate new land areas and ensure feed for larger herds. It also simplifies labour organisation, as was probably the case with the Vé-M, the shepherd who, despite a $50 \%$ similarity to Prototype II, had a $35 \%$ similarity to Prototype IV because most of his land was fenced in and because of year-round outdoors rearing of part of his flock. Furthermore, it is not difficult for these systems to respect some bans or commitments for some zones in some seasons. They are based on relatively standardised technical knowledge, both as concerns the installation and maintenance of fencing and the rhythm of utilisation and stocking rates of the paddocks according to existing pastoral standard references.

\section{DISCUSSION}

In the presentation of our results, we discuss content and validity to describe the diversity of farms (5.1.) and their contribution to improving knowledge on the linkage of space and time in farmers' strategies (5.2.).

\subsection{Attributes and categories to represent farm diversity: methodological issues}

\subsubsection{The construction of a multi-attribute grid}

\section{The domain of validity of attributes for sheep farms and other farms}

The diversity of cases studied (see Sect. 3.1.1) assures us of some completeness in the definition of relevant attributes for characterising the spatial organisation of sheepfarms in the south of France. They are also probably appropriate for characterising other livestock farms (goat or cattle farms) in other regions if they rely, at least partly, on grazing. But these attributes may not fit other farms as they are strongly linked to husbandry practices (housing flock, capacity of animals to move about and grazing modes, see Sect. 2.3). Some of them may be adapted to cropping practices (for example, land granularity or land specialisation may be an interesting feature to characterise the distribution of crops in the farmland throughout the years). Some other attributes have to be established by studying cropping practices.

Concerning sheep farms, the validity of these attributes encounters two limits that need to be borne in mind, i.e. the herders' choice in winter management and the summer transhumance. These two elements are not covered in our study and can have important effects on farmland utilisation and configuration:

- in overwintering, the length of which depends on the region, animals may be kept in buildings where supplies are distributed, or may be fed fully or partly by grazing the standing grass or winter regrowth. Such a choice has a considerable effect on spring grazing in these same areas;

- in far-off summer transhumance, the use of pastoral and fodder areas near the main farmstead will depend on the duration of summer grazing. Annual on-farm labour organisation will also depend on the conditions of animal supervision during transhumance (owner keeps the animals or boards them out).

Seeking to produce data we lack on practices connected to overwintering and transhumance will certainly lead us to working further on the definition of Attributes 7 "Role of fodder areas in building up supplies, and in springtime grazing" and 8 "Relations between rangelands and grasslands in springtime grazing”.

\section{Domain of validity of attribute modalities} within the 8-attribute grid

If we purport that the 8-attribute grid is capable of characterising spatial organisation of the very large majority of livestock farms that, in part, rely on the grazing of pastoral lands, the modalities distinguished for each of the attributes must undoubtedly be connected to the 16 cases studied. Actually, if by construction, the extreme modalities of each attribute are accurately identified, there is no reason for new cases not to be characterised by intermediary modalities other than those already distinguished for our 16 cases. As an example, for Attribute 1, "Night-time penning", the two extreme modalities, viz. "house animals throughout the year" and "leave the animals outside, regardless of season", are obvious, but rather than distinguishing one intermediary modality, as was done in this study, maybe several should be distinguished.

Accuracy of information collection necessary to classify a new case in the grid or to set up a new grid

It is necessary to distinguish between the protocol necessary to set up a new grid and the information sufficient to compare a new case to an already established grid. 
The setting up of our 8-attribute grid has taken advantage of the different accuracy levels of information compiled predicating on the observation protocols (monitoring, multi-run survey or one-time interview, see Sect. 3.1) selected in this research operation. The very detailed information coming from monitored farms, but also the involvement of some of us in long-term research operations, gave us a deep insight of farmers' practices and objectives which was fundamental to give sense to raw data. Nevertheless, the less precise protocols, i.e. one-time interviews, provide enough information to accurately characterise the different cases in relation to Attributes 1 and 3, which mainly concern land configuration, and Attribute 4 on grazingland allocation. For Attributes 2 "Management of distance the animals must cover to reach the grazing area" and 6 "Land use specialisation", the map of the farm and the general structure of the grazing calendar have turned out to be enough. We therefore now assume that a very light protocol (with a one-hour single interview) can be sufficient to characterise new sheep farms for the purpose of this 8-attribute grid.

Nonetheless, for herders who tend their animals, more careful thought has to be given to characterising Attribute 5, "Land use granularity", for which it is not easy to find information in a single interview on how the herder supervises his animals (e.g. does the herder keep a close watch by keeping the animals within a given area and targeting a specific resource, or is the grazing circuit designed to take animals from one sector to the other?).

Regarding our experience building this grid, the protocol and information required to formalise a new grid must be based on a good understanding of the targeted farmers' practices, in order to ensure a good match between them and the categories. This requirement may be seen as a limitation, but this knowledge may exist before the categorisation procedure or can be created by a specific survey (but not necessarily detailed monitoring). The characteristics of this survey protocol (and especially the number of sampled farms) must depend both on the number of farms in the targeted area and the focused practices. As far as we can draw conclusions from the diverse categorisation work we are currently carrying out, it seems that, within a targeted population with relatively homogeneous production and pedoclimatic conditions a relatively small sample of farms (e.g. 30 farms for a targeted population of 1000 cattle farms in a mountain region [60]) represents all the different practices: more farms would just generate more of the same information. Beyond these practical elements, such a typology has to be built by specialists of the domain in order to have a sense of the specific action they want to perform using these categories, as defended by [26].

\subsubsection{Categories produced}

\section{"Constructed types"}

In this study we decided to adopt the prototypes theory to express the graduality we identified in farm diversity. This choice places our prototypes explicitly among the "constructed types", as Jollivet [40] calls them. These types are produced by methods which stem from a certain number of hypotheses on the nature of the studied object, and are not "extracted" using automated methods. We used knowledge engineering tools to formalise these categories, taking as the basis the farm case studies, and our knowledge of how these farming systems function, as we said above, considering the protocol required for building a new grid. The benefits and limits of knowledge engineering tools are discussed elsewhere [32]. Nonetheless, we want to point out that the linearity within an attribute's modalities, imposed by the repertory grids, constitutes the main constraint for these tools, because trying to enter different practices on the same axis is artificial. We overcame the problem by eliminating the tool as soon as the categories had been formalised enough to do without it.

By thus producing "constructed types", we join most of the typological approaches currently being developed $[15,44]$ and which all rely on the farm functioning theory considered as a "complex managed system" [65].

\section{Farm prototypes, an innovation in typological procedures in agriculture}

Beyond this basic convergence, our approach differs from classical typological procedures through its utilisation of the prototypes theory which impacts the nature and contents of categories produced.

Farms are not assigned to one type and one type alone, as is usually done in France's agricultural census or in regional typologies, like Cristofini's [19]. With constructed prototypes, we can propose a farm classification based on a measurement of the farm's distance from (i.e. its similarity to) each of the types. From this vantage point, our procedure matches the typology constructed around Perrot's [68] "aggregation poles". Our hypothesis is that the distance between a farm and one or more types can be used to adapt advice given to the farmer. It is a measure of the farm's specificity, or even its state of being at a given moment on its trajectory. Even if the approach has not yet been used by agricultural advisors, we assume that it can enable them to pinpoint the position of a farm in relation to their technical references.

On the other hand, a prototype is described in the form of a hierarchy stemming from the weighting of attributes that is specific to each prototype. The 
specificity of attributes weighting leads to a certain degree of independence among the prototypes. This is where we find a notable departure from other typologies, e.g. Cristofini's [19], in which all the types are ranked along two attributes. Our typology, thanks to its independent types, can be updated by changing, removing or adding types, without having to revisit all of them. This flexibility in advancing a typology was also used by Perrot et al. [70]. Finally, internal hierarchisation of attributes within the definition of a type may facilitate targeting objects of advice-giving, since attributes that are not relevant to the type can be left aside. For example, advice concerning the interactions between natural and cultivated plant resources to make up the animals' daily ration is not appropriate for cases close to Prototype IV, whereas it is of great interest for cases close to Prototype I.

Categories that explicitly integrate spatial aspects of farm management

One of the most original features of our work is the nature of the attributes that define the categories. First of all, the spatial aspects are not included in the current typologies until a later stage of spatialisation of types (at the level of communes, cantons or small regions) that are constructed on the basis of other criteria $[42,57]$. Further, the criteria used as the basis for these types (e.g. [18] or [68]) mainly concern the structural elements of the farm, the main production orientations and their technical/economic results. In categorising combinations of practices in this manner, we were close to the original approach developed by Cristofini et al. [20] who use the "system of practices" concept, while we focus the types on strategic elements. We are assuming that this approach will guarantee that the diagnosis and the advice given to the farm operator are more relevant, in particular in planning the future, as was emphasised by Landais [44].

\subsection{Space-time relations in farmers' strategies}

To analyse processes of change in farms requires the production of knowledge at an intermediary level, the one of technical management which connects the classical plot or animal batches level with that of the farm. This intermediary level makes it possible to analyse the twofold (functional and strategic) coherence, which is one of the constituent parts of the "technical systems" [66]. At that level, relations between planning and reactive management in strategies the farmers apply and space-time relations can be examined.

\subsubsection{Relations between planning and reactive management in the prototypes}

In management sciences, strategic planning has traditionally been differentiated from reactive management since the former is recognised as "choosing processes that determine the major orientations, the path to follow and the means to allocate" [31] while the latter is considered as the deployment of the strategy and its materialisation through actions [50]. The analysis of the various cases in our study, and more globally, the four prototypes that we constructed, thus show that there are different ways to combine planning and reactive management within a strategy.

\section{- Careful reactive management of grazing to win the planned herd-related stakes: Prototype I}

For animal production, the farms that are closest to the first prototype have the most highly planned management since they target off-season production in suckler farms or high production in dairy farms. The result is pressure on resource utilisation because of the presence of, generally, a single flock considered as a homogeneous entity with the same - high - food requirements. Thus Prototype I is based on all-season reactive management, from feed to pasture (the herder "follows the grass") for a herd whose production is very strictly planned. Resource offtake (through grazing or mowing, which is used as an adjustment action) indeed requires reactive management with numerous adjustments within a time period of one to a few days. It is based on thorough knowledge of resources within the farmland which is organised into grazing circuits. This knowledge is used in designing these circuits for "realtime" management of animal feeding and, at the same time, ensuring future supplies and resource renewal.

\section{- Planning seasonal allocations of a single herd and managing grazed intake during periods when feed is not at stake: Prototype II}

For farms that are close to Prototype II, there is less tension related to feed management thanks to the "large sizing" of the land/herd ratio, and also because the temporal organisation of production decreases the stakes related to grazed feeding (lambing in natural season, or milk production timed so that lactation is well underway when animals are turned out to grass and ends at the beginning of summer). Fixed elements, such as fencing, water points, and holding equipment guide the herder's choices in planning his land use. Reactive management may be introduced in a plan to seasonally adjust grazing management for a given batch on a given zone. The granularity of this management is coarser than in the 
preceding prototype. It is based on knowledge of the grazing sectors, where animals are taken, and where they choose resources to make up their diets. In this scenario, the herders play a more direct role in flock management on the grazing land than in resources management per se. The challenge is to put the animals in a situation that allows them to efficiently graze targeted resources, as part of a crop year plan.

- Plan seasonal allocations of batches, all the while adjusting daily feed rations: Prototype III

For farms that are close to prototype III, the stakes related to animal production are spread across the year ( 2 or even 3 lambings per year), with, moreover, some herders belonging to rather constraining systems, i.e. those who rear breeder animals within the framework of the UPRA (national union for breed improvement and reproduction). But the design of animal batches adds flexibility to both feed management and the utilisation of the diversity of resources available on the farmland. The grazing system is based on a relatively planned organisation of farmland use that is facilitated by equipment, i.e. buildings, fencing and handling pens. The result is some degree of specialisation on the farmland's heterogeneous quartiers where daily adjustments, per batch and per plot, can be rather detailed.

\section{- Carrying out a seasonal allocation programme: Prototype IV}

For farms that are close to this prototype, little is expected of the animals (natural lambing calendar, preferably hardy breeds). Land use is relatively well planned, but there are fewer direct interventions regarding the animals than in the preceding prototypes since they are limited to choice of stocking rate at grazing, and time and frequency of grazing. The result is major specialisation of utilisation units which requires other types of actions on the plant formations (like grinding and crushing the woody plants or pastoral improvements) to offset the effects of this specialisation.

\subsubsection{Identifying spatio-temporal management entities}

Using a grid that crosses space and time, and which was designed to characterise and position processing models [28], we reconsidered the attributes selected to characterise practices and combinations of practices in order to work out the position of the prototypes. This grid proposes a time-space distinction according to the granularity of the spatio-temporal entities. The distinction between "fine" and "coarse" in the granularity of the entities, linked to the distinction between "close" and "far", position the prototypes in relation to each other.
Relationship of the four prototypes with space and time, according to underlying space organisation patterns

The elementary figures of space organisations, which are characterised using the morphology and the topology of management entities, can therefore be identified. Lardon and Osty [47] propose, thus, distinguishing figures which are concentric, chequered, strung out and radial, according to the flock's radius of action and the modalities for area allocation [64]. The distance attainable is more or less close (or far), depending on whether the sheep return to the sheepfold every day, are shepherded or are kept in paddocks, and whether far-off areas need management. These practices are connected to the configuration practices, such as the development of secondary sheepfolds, the installation of fences, and the improvement of access, that mitigate the distance-related effect. The assignment of areas will be more or less differentiated in time and space according to whether rangeland areas are specialised or not, whether grasslands are used for grazing or not, and whether grasslands are used in combination with the rangeland to feed the animals. Here again, the fact that utilisation practices are connected to configurations heightens the contiguity effect: area homogeneity, inclusion of grasslands in rangelands, adjacency of diversified areas, etc.

The combinations of these figures in the spatial organisation of farms show that the four identified prototypes do not have the same relation with space and time. Thus, if Prototype I can finely manage the area near a concentric farmland, Prototype II lessens the constraints of detailed management by taking advantage of the existence of a radial farmland centred on the farmstead, from where all sectors are equally accessible. Conversely, Prototype III has coarser management, even far off, that is based on a chequered farmland whose utilisation is generally planned. Prototype IV draws on contiguity to manage distance using a coarse granularity; it focuses on the configuration of its strung out territory.

\section{From organisational forms to territorial interests}

On the whole, the identification and analyses of spatio-temporal entities involved in the functioning of livestock farms make it possible to develop a dynamic vision of space utilisation. Attention to the farm's trajectory provides criteria for diagnosing the sustainability of local forms of territorial organisation as proposed by [1] who have discussed the application of this concept to territorial structures. Knowledge of the interlinkage of time and space is vital in grasping the impact of livestock operations on the environment and their contribution to landscape-related production [45]. When management entities have been identified, proposals can be envisioned that may be relevant to the stakeholders. But herders are 
usually not the sole owners, nor the sole users of their farmlands. How these entities are linked to other entities and levels still needs to be studied, as was suggested by [30].

\section{PERSPECTIVES AND CONCLUSION}

This study is the first step in producing a methodology for on-farm advising. To advance our approach to a more operational phase, we need to go beyond the elements discussed above and, from the same point of view, examine the limits and perspectives of our approach.

\section{On defining the domain of application}

To begin with, as was discussed in the preceding section, we feel that our grid is, to some extent, linked to our sample, but could be adapted to other livestock farms without major difficulties. For other farms, new attributes have to be set up, keeping in mind that categories must be formalised with regard to the action for which they are intended, as defended by [26].

But it must be made clear that the major contribution we intend to present here is the categorisation procedure, and not the result of it which is necessarily, to some extent, linked to the specific purposes of the modellers. Although it has not been proved formally yet, current research on farm typologies shows that this iterative process, with multiple loops between cases, attributes and categories (as described in [32]) can be used as a general guideline to support collaboration between extensionists and researchers on farm categorisation.

Secondly, our experience in sheep farms shows that it is possible - and worthwhile - to formalise attributes on spatial characteristics which make farmer's utilisation of space understandable and initiate an understanding space of the place of agriculture in space management.

\section{Formulating advice adapted to the diversity of situations}

The value of having developed a method that prioritises the identification of combinations of practices is that it implicitly takes account of the factors in a production system that condition these practices, e.g. labour organisation on a farm, or the expertise the farmer uses in his work. These elements are vital in matching advice to a given situation and in ensuring the relevance of decision support which can be formulated for the farmers.
In the particular case of sheep farms for example, the demands of animal herding and shepherding are very great in the first two types; other tasks such as, in particular, haymaking, can be done in the middle of spring by temporarily using specially enclosed paddocks. The knowledge and know-how used are not the same in the two situations:

- in the first case, they focus on building up rations for the animals through a synergetic combination of various types of resources available on the farmland; cultivated resources play a non-negligible role and are combined with spontaneous vegetation. An added piece of land means an extra period gained in the daily grazing circuit;

- in the second case, the knowledge used focuses on the assignment of each part of the farmland, which is organised into sectors, to different saisons-pratiques. An extra area here means an extra useable period in the year. That is why these systems are more adaptable than the first ones.

New forms of activity can be found in the other two types: installing and maintaining fences, building and maintaining water points, corrals and handling pens, etc. Flock supervision is no longer so systematically consuming although it still has an important role in the third type. These new tasks - which can be broken down into activity types, as has already been discussed - are postponable; in other words, it is possible to plan their occurrence and to modulate them in relation to other activities (agricultural or non-agricultural) which are less flexible. In this context, livestock production practices are not based on the same know-how as in the preceding situations: a shepherd has less need to have his seniors teach him how to motivate an animal to consume this or that plant than to know how to operate an electric fence or an automatic drinking trough or to apply per hectare stocking criteria, in other words, data provided by the technical support services.

\section{Coping with dynamic situations}

In the present situation, farms are constantly solicited by a variety of factors of change which means that the practicability of this sort of typology hinges on an ongoing evaluation of its capacity to account for farm changes and assess their potential capacity to keep apace of changes in agricultural and international policies.

Admittedly, this categorisation expresses a dynamism just as much as a state: we have seen that the third prototype represented farms that were growing and that, for the most part, stemmed from the first prototype. This means that increases - in animal numbers or land 
area - for the first type requires the development of several poles, and thus, considerable investment. Furthermore, in this management mode, the flock has to be divided into several batches, based on criteria that have to be defined on a case by case basis, and resource management has to be more thoroughly planned, a process that involves the acquisition of new forms of knowledge on the utilisation and sustainability of these resources. We also saw that a farm of the second type tended to evolve most easily into the fourth type because the technical rationales are not very different. It is actually just a question of means to equip a farmland differently.

The knowledge that scientists and engineers from the extension offices will have to produce to provide assistance in decision-making will not be the same. The latter case (Prototype IV) will require the production of sets of references that are sufficiently inclusive to cover the full range of possible situations. In the first case (Prototypes I and III), on the other hand, the brief is to help the herder with his strategic line of reasoning so that he can organise his choices and allocate the appropriate resources, in other words, what is involved here are analytical tools and interactive simulation tools rather than theoretical references in the usual sense of the term.

\section{To end with a decision support capacity to meet territorial stakes}

Our purpose is to use a relatively simple entry point that focuses on modalities for land utilisation in livestock farms, in order to avail of a representation of the stakes connected to a farm's land development. This is an issue that is arising more and more often thanks to the prospects made feasible by agro-environmental policy, and by the spontaneous dynamics of farm expansion onto rangelands and of increases in herd sizes. These are questions that have received little attention up to now and for which both herders and extensionists lack the tools needed to explore the various options now available. All these issues, especially those related to biodiversity, landscape management or even water quality, with spatio-temporal processes directly question how the farm territory is organised and used. Our purpose is not to suggest solutions to these issues but to produce tools that can be useful in designing local solutions. We feel that such tools must be relatively easy to use, but must cover the various factors that might affect the land utilisation modes, although these factors are not always explicit in discussions, which are often initially based exclusively on mappable elements. Modelling, and in particular knowledge modelling as described in this paper, is central in this problem-oriented approach, since it can be used to represent properties that stem from practices and then organise them at a broad level of knowledge.

Acknowledgements: Our gratitude goes first to the herders who were kind enough to participate in the monitoring work and surveys on which this study was based. Further, thoughts expressed in this paper benefited greatly from discussions with engineers at the Lozère Chamber of Agriculture and teachers at the Centre d'Experimentation Pédagogique in Florac. Lastly, our work was funded through an INRA Action Incitative Programmée entitled Planification et Aide à la Décision en Production Végétale.

\section{REFERENCES}

[1] Albaladejo C., Duvernoy I., La durabilité des exploitations agricoles de fronts pionniers vue comme une capacité d'évolution, in: Les temps de l'environnement, Actes des journées du PIREVS, Toulouse, 1997, Tome 1, pp. 203-210.

[2] Aubry C., De la parcelle cultivée à la sole d'une culture : des échelles complémentaires de conception des références techniques, Actes du symposium Farming Systems and Extension, Montpellier, 1994, pp. 519-525.

[3] Aubry C., Biarnes A., Maxime F., Papy F., Modélisation de l'organisation technique de la production dans l'exploitation agricole : la constitution de systèmes de culture, in: Brossier J., Dent B. (Eds.), Etud. Rech. Syst. Agraires Dév. 31 (1998) 25-43.

[4] Auricoste C., Deffontaines J.P., Fiorelli J.L., Langlet A., Osty P.L., Points de vue d'agronomes sur les potentialités agricoles. Le cas des Vosges et des Causses, in: Friches, parcours et activités d'élevage, INRA Ed., Paris, 1983, pp. 1-55.

[5] Bellon S., Girard N., Guérin G., Caractériser les saisonspratiques pour comprendre l'organisation d'une campagne de pâturage, Fourrages 158 (1999) 115-132.

[6] Benoit M., Un indicateur de risque de pollution azotée nommé BASCULE (Balance Azotée Spatialisée des Systèmes de Culture de l'Exploitation), Fourrages 129 (1992) 95-110.

[7] Benoit M., Saintot D., Gaury F., Mesures en parcelles d'agriculteurs des pertes en nitrates. Variabilité sous divers systèmes de culture et modélisation de la qualité de l'eau d'un bassin d'alimentation, C. R. Acad. Agric. Fr. 81 (1995) $175-188$.

[8] Bertrand G., Pour une histoire écologique de la France rurale, in: Duby G., Wallon A. (Eds.), Histoire de la France Rurale. T. 1 : La formation des campagnes françaises, des origines au XIV ${ }^{\mathrm{e}}$ siècle, 1975, pp. 34-112.

[9] Biarnes A., Milleville P., Du fonctionnement de l'agrosystème aux déterminants des choix techniques, in: Orstom (Ed.), La conduite du champ cultivé. Points de vue d'agronomes, Coll. Colloques et Séminaires, 1998, pp. 13-23.

[10] Blanchemain A., Présentation des parcours méditerranéens. Quelques aspects historiques, in: Molénat G., Jarrige R. (Eds.), Utilisation par les ruminants des pâturages d'altitude et parcours méditerranéens, Actes des $10^{\text {es }}$ Journées du Grenier de Theix, INRA, 1979, pp. 343-360. 
[11] Boyazoglu J., Flamant J.C., Mediterranean systems of animal production, in: Galaty J.G., Douglas D.L. (Eds.), The world of pastoralism. Herding systems in comparative perspective, The Guilford press, New York, 1990, 436 p., pp. 353-393.

[12] Bonnamour J., Bilan de l'approche géographique des exploitations agricoles. Les Cahiers de Fontenay $n^{\circ} 7$ Géographie des exploitations agricoles, ENS de Fontenay-auxRoses, 1977, pp. 5-64.

[13] Brochet M., Cavalié J., Pillot D., de Reynal V., Systèmes agraires et développement en Haïti, in: Caribbean Seminar on Farming Systems Research Methodology, Pointe à Pitre, F.W.I., IICA-INRA (Eds.), 1980, pp. 73-81.

[14] Brunet R., La composition des modèles dans l'analyse spatiale. L'espace géographique 4 (1980) 253-265.

[15] Capillon A., Typologie des exploitations agricoles. Contribution à l'étude régionale des problèmes techniques, Thèse Doct. INA P-G, Paris, 1993.

[16] Capillon A., Caneill J., Du champ cultivé aux unités de production : un itinéraire obligé pour l'agronome, Cah. Sci. Hum. 23 (1987) 409-420.

[17] Capillon A., Leterme Ph., David G., Une typologie d'exploitations préalable à la recherche de références techniques. Cas du Boischaut et de la Marche du Cher, C. R. Acad. Agric. Fr. (1984) 344-353.

[18] Capillon A., Manichon H., Une typologie des trajectoires d'évolution des exploitations agricoles (principe, application au développement agricole régional), C. R. Acad. Agric. Fr. (1979) 1168-1178.

[19] Cristofini B., La petite région vue à travers le tissu de ses exploitations : un outil pour l'aménagement et le développement rural, Etud. Rech. Syst. Agraires Dév., nº 6, 43 p., 1985.

[20] Cristofini B., Deffontaines J.P., Raichon C., De Verneuil B., Pratiques d'élevage en Castagniccia. Exploration d'un milieu naturel et social en Corse, Études Rurales 71-72 (1978) 89-109.

[21] Culos X., Lardon S., Osty P.L., Triboulet P., Modèle de représentation de l'organisation spatio-temporelle des activités d'élevage. Calendriers de pâturage d'ovins sur le causse Méjan (Lozère), in: Christophe C., Lardon S., Monestiez P. (Eds.), Étude des phénomènes spatiaux en agriculture, INRA Editions, Paris, Série Colloque, 1996, pp. 293-300.

[22] Deffontaines J.-P., Du paysage comme moyen de connaissance de l'activité agricole à l'activité agricole comme moyen de production du paysage. Un point de vue d'agronome, C. R. Acad. Agri. Fr. Coll. Paysage et Agriculture. Orientations de la recherche et préoccupations de la société 82 (1996) $57-69$.

[23] Diarra S., Les stratégies spatiales des éleveurs-cultivateurs peul du Niger central agricole, in: Maîtrise de l'espace agraire et développement en Afrique tropicale, Logique paysanne et rationalité technique, ORSTOM Ed., Paris, 600 p., 1979, pp. 87-91.

[24] Doré T., Sebillotte M., Meynard J.M., A diagnostic method for assessing regional variations in crop yield, Agric. Syst. 54 (1997) 169-188.
[25] Dubois D., Catégorisation et cognition « 10 ans après » : une évaluation des concepts de Rosch, in: Dubois D. (Ed.), Sémantique et cognition. Catégories, prototypes, typicalité, CNRS Ed., Paris, 1991, 2nd ed., 1993, pp. 31-54.

[26] Dubois D., Fleury D., Mazet C., Représentations catégorielles : perceptions et/ou action ?, in: Weill-Fassina A. (Ed.), Représentations pour l'action, Toulouse, Octarès, 1993, p. 93 .

[27] Duvernoy I., Use of a land cover model to identify farm types in the Misiones agrarian frontier (Argentina), Agric. Syst. 64 (2000) 137-149.

[28] Faivre R., Lardon S., Monestiez P., Triboulet P., Formalisme M-D-Q pour les processus spatio-temporels, Rev. Int. Géomatique 99/1 (1999) 101-121.

[29] Gaines B.R., Shaw M.L.G., Knowledge acquisition tools based on personal construct psychology, Knowl. Eng. Rev. 8 (1993) 49-85.

[30] Gautier D., Lardon S., Osty P.L., Recherche d'entités spatio-temporelles pour modéliser les dynamiques de mise en valeur de l'espace rural : des quartiers ruraux sur le Causse Méjan ? in: Les temps de l'environnement, Actes des Journées PIREVS-CNRS, Toulouse, Tome 2, 1997, pp. 125-132.

[31] Gervais M., Contrôle de gestion et planification de l'entreprise, Economica Ed., 1991.

[32] Girard N., Formaliser des prototypes de comportement d'agriculteurs, Actes des Journées Ingénierie des Connaissances IC'99, École Polytechnique Palaiseau, 1999, pp. $141-150$.

[33] Guérin G., Bellon S., Analyse des fonctions des surfaces pastorales dans des systèmes de pâturage méditerranéens, Études et Recherches Syst. Agraires Dév. 17 (1990) 147-158.

[34] Haggett P., L'analyse spatiale en géographie humaine, Armand Colin (Ed.), Coll. U Géographie, 1973.

[35] Hénin S., Sebillotte M., Si nous parlions « Assolement », Bull. des CETA, Étude n 763, 1962.

[36] Hubert B., Pastoralisme et territoire. Comment modéliser des pratiques d'utilisation, Cah. Agric. 3 (1994) 9-22.

[37] Hubert B., Girard N., Lasseur J., Bellon S., Les systèmes d'élevage préalpins. Derrière les pratiques, des conceptions modélisables, Études et Recherches Syst. Agraires Dév. 27 (1993) 351-385.

[38] Huteau M., Organisation catégorielle des objets sociaux. Portée et limites des conceptualisations de E. Rosch, in: Dubois D. (Ed.), Sémantique et cognition, Catégories, prototypes, typicalité, CNRS Ed., Paris, 1991, 2nd ed., 1993, pp. 71-88.

[39] Jarrige R., Ruminant nutrition. Recommended allowances and feed tables, Paris INRA, Paris, John Libbey Eurotext, 389 p., 1989.

[40] Jollivet M., D’une méthode typologique pour l'étude des sociétés rurales, Rev. Fr. Sociol. VI (1965) 33-54.

[41] Josien E., Dedieu B., Chassaing C., Étude de l'utilisation du territoire en élevage herbager. L'exemple du réseau extensif bovin Limousin, Fourrages 138 (1994) 115-134. 
[42] Joulie I., Perichon C., Pons Y., Steyaert P., Une typologie d'exploitations spatialisées : outil de diagnostic régional de l'agriculture, Econ. Rurale 236 (1996) 16-27.

[43] Laca E.A., Ortega I.M., Integrating foraging mechanisms across spatial and temporal scales, in: West N.E. (Ed.), Rangelands in a Sustainable Biosphere, Proc. Vth Int. Range. Congr., Salt Lake City, Utah, 1995, pp. 129-132.

[44] Landais E., Typologies d'exploitations agricoles. Nouvelles questions, nouvelles méthodes, Econ. Rurale 236 (1996) 3-15.

[45] Landais E., Perrot C., Pierret P., Maigrot J.L., Mignolet C., Zanchi E., Systèmes techniques agricoles, organisation de l'espace rural et production de paysage. Le projet MAP (Modélisation, Agriculture et Paysage), Journées du PIREVS, Paris, 1996, pp. 105-114.

[46] Lardon S., Osty P.L., Triboulet P., Élevage et éleveurs du Causse-Méjan (Lozère). Dynamique de mise en valeur et contrôle de l'espace, in: Bonniol J.L., Saussol A. (Eds.), Grands Causses Nouveaux enjeux, nouveaux regards, Fédération pour la vie et la Sauvegarde du Pays des Grands Causses, Millau, 1995, pp. 219-242.

[47] Lardon S., Osty P.L., Time-space dimensions of farmers' practice: methodological proposals from surveys and modelling of sheep farming, Case studies in Southern Massif Central, France, Fourth European Symposium, European Farming and Rural Systems Research and Extension into the next Millenium, Environmental, Agricultural and Socio-economic Issues, Volos, Greece, 3-7 April, 2000.

[48] Léger F., Référentiel Pastoral Parcellaire : construction à dires d'experts d'une typologie des stratégies d'alimentation, Paris, Institut de l'Élevage, Compte rendu n 9983310, 1998.

[49] Lericollais A., Sob, étude géographique d'un terroir sérer (Sénégal), Maison des Sciences de l'Homme-OrstomÉcole Pratique des Hautes Études (Eds.), Coll. Atlas des Stuctures Agraires au sud du Sahara, Paris-La Haye, 1972.

[50] Lorino P., Le contrôle de gestion stratégique. La gestion par les activités, Dunod Ed., Paris, 1991.

[51] Martin P., Papy F., Souchère V., Capillon A., Maîtrise du ruissellement et modélisation des pratiques de production, Cah. Agric. 7 (1998) 111-119.

[52] Martinand P., Millo A., Différenciation du territoire des exploitations ovines des préalpes du Sud en fonction de l'utilisation pastorale, in: Molénat G., Jarrige R. (Eds.), Utilisation par les ruminants des pâturages d'altitude et parcours méditerranéens, Actes des $10^{\text {es }}$ Journées du Grenier de Theix, INRA, 1979, pp. 397-407.

[53] Maxime F., Mollet J.-M., Papy F., Aide au raisonnement de l'assolement en grande culture, Cah. Agric. 4 (1995) 351-362.

[54] Meuret M., Organising a grazing route to motivate intake on coarse resources, Ann. Zootech. 45 (Suppl.) (1996) $87-88$.

[55] Meuret M., Bellon S., Guérin G., Hanus G., Faire pâturer sur parcours, Renc. Rech. Ruminants 2 (1995) 27-36.

[56] Meynard J.M., La modélisation du fonctionnement de l'agrosystème, base de la mise au point d'itinéraires techniques et de systèmes de culture, in: ORSTOM (Ed.), La conduite du champ cultivé. Points de vue d'agronomes, Coll. Colloques et Séminaires, 1998, pp. 29-54.

[57] Mignolet C., Projection spatiale de la diversité des exploitations agricoles du département des Vosges, in: Christophe C., Lardon S., Monestiez P. (Eds.), Colloque Étude des phénomènes spatiaux en agriculture, Les colloques $n^{\circ} 78$, INRA, Paris, 1996, pp. 143-150.

[58] Milleville P., Dubois J.-P., Réponses paysannes à une opération de mise en valeur de terres neuves au Sénégal, in: CNRST/ORSTOM (Eds.), Maîtrise de l'espace agraire et développement en Afrique Tropicale, Logique paysanne et rationalité technique, Actes du colloque de Ouagadougou (4-8 déc. 1978), 1978, pp. 513-527.

[59] Molénat G., Jarrige R. (Eds.), Utilisation par les ruminants des pâturages d'altitudes et parcours méditerranéens, INRA, Versailles, 1979.

[60] Monier S., Fonctionnement des élevages bovins, diversité et trajectoires, dans deux cantons des Hautes-Alpes, Mémoire de fin d'études ISARA, 82 p. + annexes.

[61] Morlon P., Benoit M., Étude méthodologique d'un parcellaire d'exploitation en tant que système, Agronomie 6 (1990) 499-508.

[62] Moulin C.H., Tchakérian E., Aussibal G., Bellon S., Bonicel L., Dimanche M., Gastou T., Pinel C., Pluvinage P., Systèmes d'exploitation et stratégies territoriales des éleveurs en zone sous forte influence urbaine, Renc. Rech. Ruminants 3 (1996) 29-32.

[63] Naïtlho M., Être éleveur, c'est aussi organiser son territoire. En quoi et comment? Mémoire de fin d'études, École Nat. Sup. Agron. Montpellier, oct. 1997.

[64] Naïtlho M., Lardon S., Representing spatial organisation in extensive livestock farming, in: Integrating Animal Science Advances into the Search of Sustainability, 5th Int. Livestock Farming Systems Symp., Posieux (Fribourg), Switzerland, 19-20 August, pp. 187-190.

[65] Osty P.L., L'exploitation agricole vue comme un système. Diffusion de l'innovation et contribution au développement, Bull. Tech. Inform. 326 (1978) 43-49.

[66] Osty P.L., Lardon S., de Sainte-Marie C., Comment analyser les transformations de l'activité productive des agriculteurs : propositions à partir des systèmes techniques de production, Études et Recherches Syst. Agraires Dév. 31 (1998) 397-413.

[67] Papy F., Viaux P., Des systèmes extensifs en grande culture. Problématique et méthode d'approche. Séminaire «L'extensification : une forme de modernisation », Dijon, 23-24 oct. 1990, CIFAR Ed., 1992, pp. 19-26.

[68] Perrot C., Typologie d'exploitations construite par agrégation autour de pôles définis à dire d'experts. Proposition méthodologique et premiers résultats obtenus en Haute-Marne, INRA Prod. Anim. 3 (1990) 51-66.

[69] Perrot C., Landais E., Comment modéliser la diversité des exploitations agricoles? Les Cahiers de la RechercheDéveloppement, CIRAD 33 (1993) 24-40. 
[70] Perrot C., Pierret P., Landais E., L'analyse des trajectoires des exploitations agricoles. Une méthode pour actualiser les modèles typologiques et étudier l'évolution de l'agriculture locale, Econ. Rurale 228 (1995) 35-47.

[71] Pierret P., Perrot C., Thinon P., Joly D., Landais E., De l'activité agricole au paysage. Une démarche de modélisation. $3^{\text {es }}$ Renc. Rech. Ruminants, INRA et Institut de l'Élevage, Paris, 1996, pp. 1-2.

[72] Rellier J.P., Marcaillou J.C., Modèles de raisonnement en conduite de cultures et conséquences pour les systèmes d'aide à la décision, Agronomie 10 (1990) 487-498.

[73] Rosch E., Classification d'objets du monde réel : origines et représentations dans la cognition, in: Ehrlich S., Tulving E. (Eds.), Bull. Psychol., numéro spécial La mémoire sémantique (1976) 242-250.
[74] Sautter G., en collaboration avec Pellissier P., Bilan et perspectives d'une recherche sur les terroirs africains et malgaches 1962-1969, Études Rurales 37-39 (1970) 7-45.

[75] Sebillotte M., Soler L.G., Les processus de décision des agriculteurs, in: Brossier J., Vissac B., Le Moigne J.L. (Eds.), Modélisation systémique et système agraire. Décision et organisation, Actes du séminaire du département de recherche sur les Systèmes Agraires et le Développement, St Maximin, mars 1989, 1990, pp. 93-117.

[76] Stone N.D., Buick R.D., Roach J.W., Scheckler R.K., Rupani R., The planning problem in agriculture: Farm-level crop rotation as an example, AI Appl. 6 (1992) 59-75.

[77] Wieber J.C., Brossart T., Essai de formulation systémique d'un mode d'approche du paysage. Etablissement d'un modèle régional de classification des paysages, Bull.Assoc. Géogr. Fr. nº 57 (1980). 